\title{
Foreign Direct Investment and External Financing Conditions: Evidence From Normal and Crisis Times *
}

Rodolphe Desbordes ${ }^{1}$, Shang-Jin Wei ${ }^{2}$

${ }^{1}$ University of Strathclyde, Glasgow G4 0GE, UK, rodolphe.desbordes@strath.ac.uk

${ }^{2}$ Asian Development Bank, Manilla 1550, Philippines, swei@adb.org

\begin{abstract}
This paper investigates the effects that external financing conditions in source and destination countries have on foreign direct investment (FDI) in normal and crisis times, using a difference-indifferences approach. We find that source and destination countries' financial development have a strong positive impact on the relative volume of FDI in financially vulnerable sectors in normal times. On the other hand, during the 2008-2010 global financial crisis, the relative volume of FDI in financially vulnerable sectors fell relatively more in financially developed source and destination countries, most notably if these countries experienced a credit crisis.
\end{abstract}

Keywords: Banking crisis; credit crisis; credit constraints; financial development; foreign direct investment; global financial crisis. JEL classifications: F23; O16.

*We would like to thank Celine Azemar, Luc Laeven, Stuart McIntyre, Ian Wooton, and two anonymous referees for helpful comments and suggestions. This paper was completed while Rodolphe Desbordes was visiting DECTI, World Bank. The authors gratefully acknowledge financial support from the Scottish Institute for Research in Economics (SIRE). 


\section{Introduction}

Foreign direct investment (FDI) financial flows declined drastically during the recent global financial crisis. According to UNCTAD statistics, whereas global FDI flows increased by $35 \%$ in 2007 , they decreased by $12 \%$ in 2008 and a further $41 \%$ in 2009 . The fact that this abrupt fall coincided with a deterioration of credit conditions worldwide suggests that credit constraints in source and destination countries have been one of the factors hindering the expansion of multinational enterprises (MNEs) abroad. While this possibility has been evoked in various policy reports, e.g. UNCTAD (2010), it has yet to be investigated rigorously. This is the aim of this paper, in which we also explore the effects of external financing conditions on FDI in 'normal' times, i.e. when financial systems are functioning properly.

There are several channels through which a credit crisis can have an influence on FDI. ${ }^{1}$ In addition to curtailing access to external finance, it depresses demand, reduces firms' self-financing capabilities, and increases uncertainty. The presence of one or several of these factors typically leads to a fall in inward and outward FDI. ${ }^{2}$ Testing directly for the impact of a credit crisis on outward and inward FDI would amount to confounding these different effects. To identify a potential 'credit channel' impact of the global financial crisis, we adopt a difference-in-differences approach, where we simultaneously exploit the variation in financial vulnerability across manufacturing sectors, ${ }^{3}$ the variation in financial development across source and destination countries, and country-specific changes in credit conditions during the 2008-2010 period.

The intuition underlying our difference-in-differences approach is that the ability of firms to finance

\footnotetext{
${ }^{1}$ In the context of this paper, FDI is defined as the initial fixed costs incurred by a firm expanding its activities outside the territorial boundaries of its home country through the establishment (greenfield FDI) or the acquisition (M\&A FDI) of a foreign affiliate, whatever the sources of funds for this expansion. Due to data availability, we focus on greenfield FDI.

${ }^{2}$ Broner et al. (2013) provide descriptive evidence that inward and outward financial FDI flows systematically decline in countries experiencing a banking crisis.

${ }^{3}$ Following Manova (2013), we define financially vulnerable firms as firms with high requirements for external capital and/or firms with few assets that can be used as collateral. The varying prevalence of these firms in each sector translates into sectors which differ in their financial vulnerability.
} 
the large upfront fixed costs of engaging in FDI with internal funds varies across sectors. ${ }^{4}$ FDI in financially vulnerable sectors is likely to be more sensitive to external finance availability, in source and destination countries, than FDI in other sectors. This has two implications. Holding other factors constant, in 'normal' times, the ratio of FDI in financially vulnerable sectors to FDI in other sectors ought to be larger in countries characterized by high financial development in both source and destination countries, whereas in '(credit) crisis' times, the relative volume of FDI in financially vulnerable sectors ought to fall relatively more in deep financial systems than in shallow financial systems. We test these two implications in this paper. By focusing on this specific link between sector-specific financial vulnerability and country-specific external financing conditions, we increase the likelihood that our results reflect the causal impact of external financing conditions on FDI.

Variants of this difference-in-differences approach, initially suggested by Rajan and Zingales (1998), have been used to study the impact of structural cross-sectional differences in financial development on international trade (Beck, 2002, 2003; Amiti and Weinstein, 2011; Manova, 2013) as well as to investigate the detrimental financial effects of the 2008-2010 global financial crisis on international trade (Bricongne et al., 2012; Chor and Manova, 2012). However, we are the first study to implement it to examine the influence of external financing conditions on FDI both in 'normal' and 'crisis' times. This is possible thanks to our access to a unique database on sector-specific real greenfield manufacturing FDI. Using this database, we are able to contribute to the limited literature on the causal effects of source and destination countries' financial development (SFD and DFD) on FDI. ${ }^{5}$

Our empirical results indicate that external finance availability in source and destination countries

\footnotetext{
${ }^{4}$ Engaging in FDI involves large upfront fixed costs related to market research, the modification of products to meet foreign tastes or regulatory requirements, or the establishment of distribution and servicing channels. Some of these costs may have to be incurred once and may not apply for follow on investments. However, crucially, each new FDI project also involves establishing or purchasing a production facility in the destination country.

${ }^{5}$ On the source side, Klein et al. (2002) is one of the rare papers examining this issue. It shows that the FDI activity of Japanese firms in the United States during the Japanese banking crisis in the nineties was inversely correlated with the deterioration of the financial health of their main bank, as measured by Moody's downgrades. On the destination side, Desai et al. (2006) and Antras et al. (2009) find, using ingenious natural experiments, a positive impact of DFD on FDI. See also Bilir et al. (2014).
} 
plays an important role in the international expansion of firms through greenfield FDI, especially in financially vulnerable sectors. In normal times, defined as the period 2003-2007, SFD and DFD have a positive influence on the relative volume of FDI in financially vulnerable sectors. On the other hand, during the 2008-2010 global financial crisis, the relative volume of FDI in financially vulnerable sectors fell relatively more in financially developed source and destination countries. ${ }^{6}$ These effects are large, statistically and economically significant, and robust to various specification tests, including controlling for economy-wide and sector-specific output. Taking into account, in a second stage, that the degree of tightening of credit conditions during the global financial crisis differed across countries -some of them experienced a banking crisis- reinforces our results. Finally, we find that external financing conditions influence FDI at both the extensive (number of projects) and intensive (average size of project) margins in normal times, whereas during the global financial crisis, firms have responded to credit constraints by reducing mainly the size of their foreign projects. Overall, these results suggest that SFD and DFD are important determinants of FDI and that tighter credit conditions are partly responsible for the drop in the volume of FDI during the global financial crisis.

The rest of the paper proceeds as follows. In section II, we introduce our difference-in-differences models. In section III, we describe the data used and explain how we estimate our econometric models. In section IV, we present our empirical results. Finally, we conclude in section V.

\section{Econometric models}

In this section, we describe in general terms the econometric models that we estimate. We will present in the next section our proxies for each variable included in our models.

We are interested in the effects of external financing conditions in source and destination countries

\footnotetext{
${ }^{6}$ As we will show in our results, the effects of tighter credit conditions in destination countries during the global financial crisis are not as robust as those in source countries. Nevertheless, in a large number of cases, the coefficients on 'destination' variables have the expected sign and are statistically significant.
} 
on FDI. Establishing a causal effect of SFD and DFD on FDI is difficult because financial development can be correlated with a large number of variable which can influence FDI, including economic growth, human capital, institutional quality, natural resources, capital controls liberalization, or foreign ownership restrictions. Our solution to isolate a credit channel is to apply the difference-in-differences approach suggested by Rajan and Zingales (1998). Their methodology relies on a simple but powerful idea: if firms are credit constrained, firms in financially vulnerable sectors should disproportionately benefit from greater financial development than firms operating in other sectors in 'normal times'. By extension, if external financing conditions truly matter, we should also find that the activities of firms in financially vulnerable sectors are much more hampered than those of firms in other sectors during times of credit crisis, especially in countries where external financing conditions were favourable pre-crisis. We incorporate these two ideas in the following exponential model:

$$
\begin{aligned}
F D I_{i j s t}= & \exp \left(\beta_{1}\left[S F D_{i} \cdot F V_{s}\right]+\beta_{2}\left[S F D_{i} \cdot F V_{s} \cdot G F C 0810_{t}\right]+\beta_{3}\left[D F D_{j} \cdot F V_{s}\right]\right. \\
& \left.+\beta_{4}\left[D F D_{j} \cdot F V_{s} \cdot G F C 0810_{t}\right]+\alpha_{i j t}+\alpha_{s}+\alpha_{s} \cdot G F C 0810_{t}\right) \epsilon_{i j s t}
\end{aligned}
$$

where $F D I_{i j s t}$ corresponds to a measure of the cumulated value of the fixed costs incurred by parent firms headquartered in source country $i$ to establish a new foreign affiliate in manufacturing sector $s$ of destination country $j$ at time $t, S F D_{i}$ and $D F D_{j}$ are pre-sample measures of financial development in source and destination countries respectively, $F V_{s}$ is a time-invariant measure of sector-specific financial vulnerability, $G F C 0810_{t}$ is a dummy variable which takes the value of one for the period 2008-2010, $\alpha_{i j t}$ are year-specific country-pair fixed effects, $\alpha_{s}$ are sector fixed effects, and $\epsilon_{i j s t}$ is a multiplicative error term.

The fixed effects that we include in our econometric model prevent us from estimating directly the effects of financial development, or of the tightening of credit conditions associated with the global fi- 
nancial crisis, on the absolute volume of FDI. However, their presence has the important advantage of reducing the possibility of our results being contaminated by an omitted variable bias due, for example, to financial development correlated with unobserved determinants of FDI or to FDI in financially vulnerable sectors being globally more sensitive to crisis-induced uncertainty than FDI in other sectors. We also maximise the sample size because we are not faced with the issue of including explanatory variables with heterogeneous spatial-temporal coverages. We use pre-sample values of financial development to avoid a potential simultaneity bias.

Identification of the effects of external financing conditions on FDI is achieved by focusing on the coefficients on the SFD-FV and DFD-FV interaction terms, $\beta_{1}-\beta_{4}$.

$\beta_{1}$ and $\beta_{3}$ indicate, holding other factors constant, the multiplicative change in (outward or inward) FDI in a given sector induced by higher financial development relative to the multiplicative change in FDI induced by the same change in financial development in a sector less financially vulnerable in 'normal times'. $\beta_{1}$ and $\beta_{3}$ correspond to the effects of financial development on the relative volume of FDI in financially vulnerable sectors. For instance, following an increase in SFD of $\triangle S F D$, the ratio of the factor change in FDI in a sector with high financial vulnerability to the factor change in FDI in a sector with low financial vulnerability is $\exp \left(\beta_{1}\left[F V_{H}-F V_{L}\right] \times \Delta S F D\right)$.

The parameters $\beta_{2}$ and $\beta_{4}$ indicate, holding other factors constant, how the relative volume of (outward or inward) FDI in financially vulnerable sectors responded to the global financial crisis in more financially developed countries. More precisely, define the relative volume of FDI (RFDI) in financially vulnerable sectors as $R F D I=\frac{F D I_{F V_{H}}}{F D I_{F V_{L}}}$. Consider two source countries, country $H$ with high financial development $\left(S F D_{H}\right)$ and country $L$ with low financial development $\left(S F D_{L}\right)$, and two periods, the pre-crisis period $(N)$ and the crisis period $(C)$. Then $\frac{R F D I_{H C}}{R F D I_{H N}} / \frac{R F D I_{L C}}{R F D I_{L N}}=\exp \left(\beta_{2}\left[F V_{H}-\right.\right.$ $\left.\left.F V_{L}\right] \times\left[S F D_{H}-S F D_{L}\right]\right) . \beta_{2}<0$ would indicate that the relative volume of outward FDI in financially vulnerable sectors fell relatively more in the high financial development country than in the low 
financial development country during the financial crisis.

Finding, on the one hand, $\beta_{1}>0 ; \beta_{3}>0$, and, on the other hand, $\beta_{2}<0 ; \beta_{4}<0$, would provide strong support for a role played by external financing conditions in shaping FDI flows in normal and crisis times, and cross-validation that the effects that we highlight in each period are not due to other factors.

The GFC $0810_{t}$ dummy variable, which is not country-specific, reflects the fact that external financing conditions deteriorated in most countries during the 2008-2010 period. Pre-crisis international financial linkages led to the propagation to the rest of the world of the negative loan supply shocks that initially occurred in developed countries (Cetorelli and Goldberg, 2010; Berkmen et al., 2012). Nevertheless, the assumption that the reduction in the availability of external finance was homogenous worldwide is likely to be too strong. Notably, in some countries, the combination of financial and real shocks generated a banking crisis, resulting in a strong impairment in banks' ability and willingness to lend. In a second stage, we take into account the possibility that credit conditions have been heterogenous across countries during the global financial crisis by estimating the following model, in which we focus on the credit channel effect of the global financial crisis:

$$
\begin{aligned}
F D I_{i j s t}= & \exp \left(\gamma_{1}\left[S F D_{i} \cdot F V_{s} \cdot G F C 0810_{t}\right]+\gamma_{2}\left[S F D_{i} \cdot F V_{s} \cdot G F C 0810_{t} \cdot I C R I S_{i}\right]\right. \\
& +\gamma_{3}\left[D F D_{i} \cdot F V_{s} \cdot G F C 0810_{t}\right]+\gamma_{4}\left[D F D_{i} \cdot F V_{s} \cdot G F C 0810_{t} \cdot I C R I S_{j}\right] \\
& +\gamma_{5}\left[F V_{s} \cdot G F C 0810_{t} \cdot I C R I S_{i}\right]+\gamma_{6}\left[F V_{s} \cdot G F C 0810_{t} \cdot I C R I S_{j}\right] \\
& +\gamma_{7} G D P G_{i t}+\gamma_{8}\left[G D P G_{i t} \cdot F V_{s}\right]+\gamma_{9} G D P G_{j t}+\gamma_{10}\left[G D P G_{j t} \cdot F V_{s}\right] \\
& \left.+\alpha_{s}+\alpha_{s} \cdot G F C 0810_{t}+\alpha_{i j s}+\alpha_{i} \cdot G F C 0810_{t}+\alpha_{j} \cdot G F C 0810_{t}\right) \epsilon_{i s t}
\end{aligned}
$$

where intensity of the crisis $(I C R I S)$ is a variable which measures the degree of tightening of credit 
conditions in a source or destination country during the global financial crisis. ${ }^{7}$ In this econometric model, we go one step further to reduce any omitted variable bias by including time-invariant sectorcountry-pair fixed effects $\left(\alpha_{i j s}\right)$. We also control for various time-varying sector fixed effects, including those related to country-specific GDP growth $(G D P G)$, and period-varying country fixed effects. ${ }^{8}$

Including sector-country-pair fixed effects prevents us from estimating the effects of SFD and DFD on the relative volume of FDI in financially vulnerable sectors in normal times. However, it is important to note that the coefficients on the interaction terms in equation (2) implicitly contrast the effect of financial development on the relative volume of FDI in financially vulnerable sectors during the global financial crisis with the effect of financial development on the relative volume of FDI in financially vulnerable sectors during pre-crisis times. In that way, estimation of these coefficients provides indirect evidence on the importance of external financial conditions for financially vulnerable FDI in 'normal' times.

$\gamma_{2}<0 ; \gamma_{4}<0$ would indicate that the negative response of the relative volume of FDI in financially vulnerable sectors in more financially developed countries was stronger, during the global financial crisis, in countries experiencing severe tightening of external financing conditions. Hence, estimation of model 2 allows us to isolate in greater depth the credit channel impact of the global financial crisis on FDI by considering the country-specific level of financial distress in the banking sector.

\section{Data and estimation method}

In this section, we define our key variables. Electronic sources of the data can be found in Appendix A.

FDI data

Our dependent variable corresponds to yearly data on sector-specific bilateral greenfield FDI during

\footnotetext{
${ }^{7}$ When $I C R I S$ is a continuous variable, the interaction terms associated with parameters $\gamma_{1}$ and $\gamma_{3}$ are omitted.

${ }^{8} \mathrm{We}$ could not obtain convergence when we tried to include in the same regression both time-invariant sector-country-pair fixed effects and year-specific country fixed effects.
} 
the period 2003-2010. More specifically, our proxy for $F D I_{i j s t}$ is the sector-specific bilateral yearly cumulated value of the capital investments made by firms headquartered in a given country to establish a new production or processing manufacturing facility in a given foreign country. This variable should capture a large fraction of the pre-sample fixed costs incurred by multinational enterprises to produce abroad when establishing a foreign affiliate ex nihilo. ${ }^{9}$ In some regressions we will also use as the dependent variable the bilateral number of greenfield FDI projects or the average size of the bilateral greenfield projects conditional on positive FDI. These represent measures of the extensive and intensive margins of FDI respectively.

Data come from the fDi Markets database compiled by FDI Intelligence, a division of the Financial Times. This database is the most comprehensive source of firm-level information on cross-border greenfield investment available, covering all countries and sectors worldwide since 2003. Data include the name of the country in which the firm engaging in greenfield FDI is headquartered, the year of investment, the destination country, the recipient sector, the function (nature) of the project, the type of project (new, expansion, co-location), and the initial capital investment (capital expenditures) associated with the FDI project. There is no minimum investment size for a project to be included but the equity stake of the foreign investor cannot be lower than $10 \%$. Data are collated through daily searches of Financial Times newswires and internal information sources, other media sources, project data received from industry organizations and investment agencies, and data purchased from market research and publication companies. Each project is cross-referenced against multiple sources, with the main focus on direct company sources. fDi Markets is the primary source of greenfield FDI data for various international organizations (UNCTAD, World Bank), consultancies (the Economist Intelligence Unit), major corporations, and over 100 governments. ${ }^{10}$

\footnotetext{
${ }^{9}$ Firms may incur other fixed costs before or after this cross-border investment. While our dependent variable does not include these costs in principle, they play a role in firms' ability to self-finance their capital expenditures abroad.

${ }^{10}$ Despite validation checks, data may include FDI projects which have been announced but have not taken place. In addition, the data include estimates for capital investment (derived from algorithms) when a company does not release
} 
Crucially for our study, the fDi Markets database does not make a distinction between the different sources of foreign affiliate financing, which can be internal or external to the MNE. Given that we are interested in the impact of both SFD and DFD on FDI flows, the absence of a distinction between internal and external financing makes the data provided by fDi Markets database a much better measure of FDI flows than balance of payments (BOP) data on financial FDI flows, which do not take into account, among other things, that a proportion of the financing for a newly-established foreign affiliate can originate from unrelated parties in the destination country. Furthermore, contrary to BOP FDI flows, our FDI data only reflect the initial fixed costs incurred by firms engaging in FDI, provide information on the extensive and intensive margins of FDI, are not distorted by 'round-tripping' and 'trans-shipping' phenomena, are recorded on a gross basis and, finally, are available for a large number of countries and sectors.

Our database only includes data on greenfield FDI. Hence, our results may not be generalisable to cross-border mergers and acquisitions (M\&A), although we note that UNCTAD (2010) reports that both greenfield and M\&A FDI flows significantly dropped during the global financial crisis. ${ }^{11}$ In addition, while the absence of M\&A FDI from our database can be seen as a drawback, it can also be interpreted as a benefit. First, we avoid any compositional bias by focusing on one particular form of FDI. Second, whereas much empirical work has been done on M\&A FDI, the determinants of greenfield FDI remains an under-researched area, despite the interest that they generate for policymakers, who see greenfield FDI as having more benefits, in terms of new jobs and production activity created, than M\&A (Sauvant, 2009).

Figure A1, in Appendix B, plots the cumulated values of outward and inward manufacturing greenfield FDI over the period 2003-2010 against economy-wide FDI flows compiled by UNCTAD on the the information. These two features of the data introduce measurement error in our dependent variable, generating larger variances in our estimators.

${ }^{11}$ The report puts particular emphasis on the role played by financial constraints to explain these concomitant trends. 
basis of BOP statistics. The latter include information on both greenfield and M\&A FDI. There is a strong correlation between the values of these two sources of FDI statistics $(r \approx 0.80 ; r \approx 0.82$ when using total greenfield FDI flows). In addition, the cumulated values, over the period 2003-2010, of economy-wide fDi Markets outward (inward) flows represent, for the 'median country', about 100\% (50\%) of the cumulated values of UNCTAD-BOP outward (inward) FDI flows. ${ }^{12}$ This suggests that the greenfield FDI data that we use in this paper are not affected by large inconsistencies and are potentially representative of trends in both greenfield and M\&A FDI.

Given that we do not have any parent-specific data, besides a numeric identifier, we can aggregate the firm-level data provided by the fDi Markets database at the country-sector level without any loss of information to obtain a proxy for $F D I_{i j s t} .{ }^{13}$ The fDi Markets database provides data on the recipient sector only. Hence, while we know in which sector the FDI project takes place, we have no information on whether the parent firm belongs to the same sector. We must therefore assume that the main sector of activity of the parent firm is the same sector as the sector in which the parent firm invests in the destination country. Failure of this assumption will obviously make our identification strategy less powerful, by blurring the potential link between external dependence and financial development. This is especially true on the source side; on the destination side, it can still be expected that MNEs wish to invest in countries where their foreign subsidiaries in need of external finance can acquire a large degree of financial autonomy through access to local sources of funding. Nevertheless, given that sector-level FDI data are aggregated at a relatively high level, it is likely that parents and foreign subsidiaries operate in the same broad manufacturing sectors. ${ }^{14}$

\footnotetext{
${ }^{12}$ However, as discussed above, these values have limited meaning given that our FDI data and the BOP FDI data do not measure the same flows.

${ }^{13}$ In unreported regressions, we attempted to take into account that large firms may face less stringent financial constraints than small firms by keeping in the sample firms which undertook at least three FDI projects during the period 2003-2010, corresponding to $10 \%$ of the parent firms in our sample (and 50\% of total investment). Our results were similar to the estimates reported in columns (1) and (2) of Table 4. The same results were obtained when we restricted the sample to firms which undertook at least five FDI projects during the period 2003-2010. Hence, it seems that source and destination countries' financial development matter for both small and large firms.

${ }^{14}$ Alfaro and Charlton (2009) find that $70 \%$ of foreign subsidiaries operate in the same manufacturing sector as their parent
} 
At the most disaggregated level, the underlying data that we use to estimate models (1) and (2) correspond to 14590 greenfield FDI projects in a new production or processing manufacturing facility made by 6811 parent companies, located in 99 source (developed and developing) countries, in 13 broad manufacturing sectors of 135 destination (developed and developing countries) during the period 20032010. ${ }^{15}$ As can be seen in Figure A1, in Appendix B, The largest sources of greenfield manufacturing FDI over the period 2003-2010 are OECD countries and the largest recipients are large emerging countries such as the BRIC countries ( Brazil, Russia, India, and China) and the United States. A detailed description of the patterns of greenfield FDI can be found in Davies et al. (2015).

\section{Sector-specific financial vulnerability}

Our main indicator of sector-specific financial vulnerability $\left(F V_{s}\right)$ is the Rajan and Zingales (1998) measure of external dependence (ED). They calculated a sector's need for external finance as the fraction of capital expenditures that were not financed with cash flows from operations for a sample of publicly traded US firms in the 1980s. For each firm, the ratio was averaged over the 1980s and the final ED measure corresponds to the sector median. The key assumption underlying the validity of their ED proxy is that the ranking it generates across sectors is stable across countries because a sector's need for external finance is intrinsically linked to sector-specific, but country-invariant, technological characteristics. By using U.S. data on publicly traded firms, Rajan and Zingales (1998) increase the likelihood that they correctly identify a sector's technological demand for external financing. Large firms typically face fewer financing obstacles than small firms and if there is any country in which firms' actual use of external finance reflects their desired level, the United States is perhaps the closest one can find given

at the two-digit SIC level. In addition, we expect the financial vulnerability of parent companies operating in various sectors to be partly affected by the dependence on external finance of the manufacturing sector in which they invest abroad.

${ }^{15}$ Firms can invest abroad in other 'functions', e.g. logistics, sales/customer support, or retail. We prefer to exclude these FDI projects from our sample because the broad sectoral classification adopted by FDI Intelligence may lead some projects to be included in a manufacturing sector even when their purposes are only to provide support services to this sector or to facilitate the distribution and sale of its products. By focusing on FDI in a new production or processing manufacturing facility (the 'manufacturing function' in the fDi Markets database), we strongly increase the likelihood that the parent firm truly belongs to the manufacturing industry. The median share of FDI in the non-manufacturing function is about $20 \%$. 
the sophistication of its financial system.

Firms which rely on external finance to conduct their day-to-day trading operations or invest in new growth opportunities at home can be expected to be those which need external financing to expand abroad. The establishment of a foreign affiliate requires substantial purchases of new foreign fixed assets, e.g. land, building, machinery. It is also plausible that any product which entails high R\&D, marketing or distribution costs at home will similarly involve large customization, marketing and distribution fixed costs when produced and sold in foreign markets (Manova, 2013). The ED measure developed by Rajan and Zingales (1998) is based on a sample of large U.S. companies, which are likely to have activities abroad. This sample composition helps to make it a good proxy for the typical external financing needs of MNEs in a given sector.

Sectors not only vary in firms' reliance on external finance but also in firms' ability to access external finance. For a given technological need for external finance, raising outside finance is likely to be easier for firms in sectors structurally characterized by a high level of tangible assets. These assets can be pledged as collateral, reducing in that way the adverse selection and moral hazard problems that lenders face. To capture this second dimension of financial vulnerability, we use the Kroszner et al. (2007) measure of asset tangibility (TANG). It corresponds to the sector-specific ratio of fixed assets to total assets and it has been calculated for the period 1980-1999 using the same methodology as Rajan and Zingales (1998). While the TANG measure is not specific to FDI activities, firms are more likely to have access to external finance, at home or abroad, when their existing assets, or the assets they wish to acquire in a foreign country, are tangible. ${ }^{16}$

\footnotetext{
${ }^{16}$ Given that our FDI variable corresponds to capital expenditures, i.e. investment in collateralizable tangible assets, it could be argued that asset tangibility is not an appropriate measure of financial vulnerability. This may have been true if external finance was only sought to cover the costs of building a new manufacturing facility. However, outside capital is also likely to be required to invest in intangible assets complementary to the tangible assets. Engaging in FDI may then be conditional on the ability of firms to finance the intangible assets that they need to operate successfully in foreign markets. This constraint should be particularly strong for firms operating in sectors where intangible assets are at the core of their business. It is also possible that sector-specific asset tangibility matters if the loan financing the FDI project is backed by the tangible assets of the parent company. That may be the case if a domestic bank does not want to deal with the seizure of
} 
Table A1 in Appendix C provides the values of the two measures of financial vulnerability for the thirteen manufacturing sectors present in the fDi Markets database. Sectors vary both in their dependence on external finance and their ability to access external finance (the coefficient of correlation between the two financial vulnerability measures is 0.04$)$. Most sectors $(85 \%)$ have a positive and large dependence on external finance (ED $\geq 0.19$ for $60 \%$ of them).

\section{Financial development}

Our main measure of financial development $\left(S F D_{i} ; D F D_{j}\right)$ is the domestic credit allocated to the private sector by banks and other financial intermediaries, normalised by GDP (CREDIT/GDP). This financial development measure, which largely reflects the actual use of external debt financing in the economy, has been extensively used in the growth, finance, and international trade literature (Levine, 2005). Data come from Beck et al. (2009). In order to reduce idiosyncratic values and avoid a potential simultaneity bias between outward FDI and financial development, we use the average values over the pre-sample period 2000-2002. The private credit to GDP ratio varies a lot across countries (standard deviation of $49 \%$ ).

We also verify that our results are robust to a time-invariant institution-based measure of financial development (FIN_INST). This measure corresponds to the sum of the values of two World Bank Doing Business indexes measuring the quality of financial institutions: the strength of legal rights index, which indicates 'the degree to which collateral and bankruptcy laws protect the rights of borrowers and lenders,' and the depth of credit information index, which assesses 'the rules and practices affecting the coverage, scope and accessibility of credit information available through either a public credit registry or a private credit bureau.' The measure ranges from 0 to 16 (worst to best) and we use the average value of each index over the 2005-2006 period to construct our institution-based measure. Development of these assets in a foreign jurisdiction. For these reasons, TANG ought to remain a valid measure of financial vulnerability, including in the context of this paper. 
two financial institutions should encourage the supply of external funds by facilitating the use of a broad range of movable assets as collateral, increasing the rights of creditors in case of bankruptcy, and reducing informational asymmetries. The coefficient of correlation between the private credit to GDP ratio and this measure of the quality of financial institutions suggests that it is indeed the case: it is equal to 0.60 , statistically significant at the $1 \%$ level.

\section{Degree of tightening of credit conditions during the global financial crisis}

We use different indicators to assess the degree of tightening of credit conditions in a given country during the global financial crisis $(I C R I S)$.

We first expect credit conditions to have significantly deteriorated in countries experiencing a banking crisis. We therefore define a banking crisis dummy variable (BCRIS) which takes the value of one if a country has been formally identified as having experienced a banking crisis during the period 20082010. We rely on the classification of Laeven and Valencia (2013) to identify banking crisis episodes. A banking crisis is characterized by significant signs of financial distress in the banking system (e.g. bank runs, large losses, bank liquidations) and large-scale policy interventions to support distressed financial institutions. Laeven and Valencia (2013) also make a distinction, that we will exploit, between borderline (two policy interventions) and systemic cases (at least three policy interventions) (SYS_BCRIS). In our sample, the 23 crisis-affected countries are: Austria, Belgium, Denmark, France, Germany, Greece, Hungary, Iceland, Ireland, Kazakhstan, Latvia, Luxembourg, Netherlands, Nigeria, Portugal, Russia, Slovenia, Spain, Sweden, Switzerland, Ukraine, United Kingdom, United States.

Following Laeven and Valencia (2013), we create an alternative measure of banking crisis which is based on the evolutions of real GDP growth and nominal private credit growth (ALT_BCRIS). This alternative banking crisis dummy variable takes the value of one if, during the period 2008-2010, a country experienced both negative real GDP growth and a slowdown in nominal private credit growth. 
The logic behind this indicator is that a genuine financial crisis entails disruptions to the supply of credit and large output losses. This variable is not simply an indicator of recession because slowdown in nominal private credit growth is also required for a country to be classified as crisis-affected. With this alternative methodology, 49 countries are identified as having suffered from a banking crisis.

Finally, we use a direct measure of how firms have perceived changes in credit conditions during the global financial crisis (CH_CRED). This measure corresponds to the relative change, between the period 2005-2007 ('normal times') and the period 2009-2010 period (crisis times), in the average answers to the following question, found in the World Economic Forum Global Competitiveness Reports: 'How easy is it to obtain a bank loan in your country with only a good business plan and no collateral? $(1=$ very difficult; 7 = very easy)'. The answers in 2008 are not included because the scores are weighted averages of the current and last years. Hence scores in 2008 partly reflect pre-crisis external financing conditions.

This measure has several advantages: i) it is a direct indicator of changes in credit conditions as perceived by firms; ii) it focuses on the supply of credit; iii) it excludes credit restrictions due to firms' balance sheet effects; iv) it can be positive (e.g. $+13 \%$ in China) or negative (e.g. $-29 \%$ in the U.S.A.). This measure is much less blunt that the previous ones presented in this section because it provides a much more granular assessment of changes in credit conditions. It is also more flexible because it allows for the possibility that some countries experienced a loosening of credit conditions during the global financial crisis.

Some descriptive statistics can be found in Tables A2 and A3 in Appendix D.

\section{Estimation method}

It is common in the FDI literature to model the conditional mean of $\ln (F D I)$ instead of the conditional mean of $F D I$. One fundamental problem with using log-linear models is that observations for 
which the FDI value is equal to zero are dropped from the sample. ${ }^{17}$ This truncation issue does not arise when the conditional mean of $F D I$ is modeled directly using an exponential function, as we have done in equations (1) or (2). Consistent estimation of the conditional mean parameters can be achieved by using a Poisson fixed effects estimator. This estimator is robust to distributional misspecification and therefore, as long as the conditional mean function is correctly specified, this estimator is consistent even if the dependent variable is continuous (Winkelmann, 2008; Wooldridge, 2010). We use the Hausman et al. (1984) conditional maximum likelihood version of the Poisson fixed effects estimator, which does not involve the inclusion of a large number of dummy variables to account for the (sector-)country-pair specific effects; the fixed effects are conditioned out from the model estimation and are therefore not treated as parameters to be estimated. Standard errors are clustered at the country level to deal with potential correlation of errors over time and across sectors.

Other methods have been suggested in the literature to deal with zero values, e.g. estimating a regression model by ordinary least squares where the dependent variable is $\ln (\mathrm{FDI})$ or $\ln (\mathrm{FDI}+\mathrm{constant})$; different variants of the Tobit model. However, the Monte-Carlo simulations of Santos Silva and Tenreyro (2006, 2011), Westerlund and Wilhelmsson (2011) and Head and Mayer (2013) indicate that all these alternative estimators to the Poisson estimator perform very poorly when the sample includes zero values and heteroskedasticity is present, as in the case of our empirical application. ${ }^{18}$ On the other hand, the Poisson QMLE is robust to various patterns of heteroskedasticity as well as to a large number of observations for which the value of the dependent variable is equal to zero, including when the reported absence of economic activity is due to the omission of small transactions. ${ }^{19}$

\footnotetext{
${ }^{17} 85 \%$ of the observations in our sample take the value of zero. They correspond to cases where no bilateral FDI in a given sector is recorded in the FDI database that we use.

${ }^{18}$ Heteroskedasticity influences the consistency of the estimators because log-linearization of multiplicative models induces a correlation between the transformed error term and the explanatory variables. In addition, simulations of the cited papers indicate that the Poisson QMLE does not suffer from an incidental parameters problem.

${ }^{19}$ Our key results are robust to the estimation of a linear regression model by ordinary least squares, where the dependent variable is not transformed.
} 


\section{Results}

\section{Baseline results and robustness checks}

Baseline results are presented in Table 1. In column (1), SFD and DFD are interacted with the sector-specific ED measure, without making a distinction between the pre- and crisis periods. The large, positive, and statistically significant coefficients on the two interaction terms indicate that SFD and DFD had, overall, large, positive, and statistically significant effects on the relative volume of FDI in financially vulnerable sectors during the period 2003-2010. These results, which are new to the literature, provide a first evidence that external financing conditions matter for FDI since they show that SFD and SFD have a disproportionately positive influence on FDI in financially vulnerable sectors. In column (2), the two interaction terms are interacted with the global financial crisis dummy variable, which takes the value of one for the period 2008-2010. The large and negative coefficients on these triple interaction terms indicate that during the global financial crisis, FDI in financially vulnerable sectors benefited to a much lesser extent from greater financial development, implying a loss of access to external finance due to tighter credit conditions. This appears to be especially true on the source side: the coefficient on the triple interaction term involving SFD is very large and statistically significant at conventional levels whereas the coefficient on the triple interaction term involving DFD is much smaller and not statistically significant. The results of column (2) provide additional evidence that external financing conditions matter for FDI, by showing that the tightening of credit conditions during the global financial crisis hit FDI harder in the more financially vulnerable sectors, especially when originating from the more financially developed source countries.

Figure 1 reports the estimated effects of SFD and DFD on the relative volume of FDI in financially vulnerable sectors in 2003 (squares) and the differences between the effects in subsequent years and these 2003 baseline impacts (dots). It can be seen that the positive effects of SFD and DFD were 
Table 1: FDI, financial development, and the global financial crisis

\begin{tabular}{|c|c|c|c|c|c|c|c|}
\hline & \multicolumn{7}{|c|}{ Volume of bilateral FDI, by sector } \\
\hline & $\begin{array}{c}\text { Full } \\
\text { period } 0310 \\
(1)\end{array}$ & $\begin{array}{c}\text { Distinction } \\
\text { GFC0810 } \\
(2)\end{array}$ & $\begin{array}{c}\text { Omission } \\
\text { China } \\
(3)\end{array}$ & $\begin{array}{c}\text { Omission } \\
\text { United States } \\
(4)\end{array}$ & $\begin{array}{c}\text { Inclusion } \\
\text { TANG } \\
(5) \\
\end{array}$ & $\begin{array}{c}\text { Inclusion } \\
\text { TANG } \\
(6) \\
\end{array}$ & $\begin{array}{c}\text { Inclusion } \\
\text { DUR } \\
(7) \\
\end{array}$ \\
\hline ED X S. CREDIT/GDP & $0.859^{* * *}$ & $1.431^{* * *}$ & $1.502^{* * *}$ & $0.999 * * *$ & & $1.040^{* * *}$ & $1.443^{* * *}$ \\
\hline ED X S. CREDIT/GDP X GFC0810 & & $\begin{array}{l}-1.438^{* * *} \\
(0.476)\end{array}$ & $\begin{array}{l}-1.544^{* * *} \\
(0.483)\end{array}$ & $\begin{array}{l}-1.163^{* *} \\
(0.507)\end{array}$ & & $\begin{array}{l}(0.280) \\
-1.279^{* * *} \\
(0.477)\end{array}$ & $\begin{array}{l}-1.440^{* * *} \\
(0.496)\end{array}$ \\
\hline TANG X S. CREDIT/GDP & & & & & $\begin{array}{l}-6.150^{* * *} \\
(1.194)\end{array}$ & $\begin{array}{l}-4.305^{* * *} \\
(0.950)\end{array}$ & \\
\hline TANG X S. CREDIT/GDP X GFC0810 & & & & & $\begin{array}{l}3.701^{* *} \\
(1.634)\end{array}$ & $\begin{array}{l}1.463 \\
(1.728)\end{array}$ & \\
\hline DUR X S. CREDIT/GDP & & & & & & & $\begin{array}{l}-0.001 \\
(0.150)\end{array}$ \\
\hline DUR X S. CREDIT/GDP X GFC0810 & & & & & & & $\begin{array}{l}-0.021 \\
(0.237)\end{array}$ \\
\hline ED X D. CREDIT/GDP & $\begin{array}{l}1.630^{* * *} \\
(0.273)\end{array}$ & $\begin{array}{l}1.782^{* * *} \\
(0.342)\end{array}$ & $\begin{array}{l}1.756^{* * *} \\
(0.359)\end{array}$ & $\begin{array}{l}1.868^{* * *} \\
(0.398)\end{array}$ & & $\begin{array}{l}1.402^{* * *} \\
(0.294)\end{array}$ & $\begin{array}{l}2.147^{* * *} \\
(0.347)\end{array}$ \\
\hline ED X D. CREDIT/GDP X GFC0810 & & $\begin{array}{l}-0.490 \\
(0.445)\end{array}$ & $\begin{array}{l}-0.809^{*} \\
(0.451)\end{array}$ & $\begin{array}{l}-0.437 \\
(0.549)\end{array}$ & & $\begin{array}{l}-0.586 \\
(0.387)\end{array}$ & $\begin{array}{l}-0.815^{*} \\
(0.469)\end{array}$ \\
\hline TANG X D. CREDIT/GDP & & & & & $\begin{array}{l}-7.623^{* * *} \\
(1.625)\end{array}$ & $\begin{array}{l}-4.825^{* * *} \\
(1.240)\end{array}$ & \\
\hline TANG X D. CREDIT/GDP X GFC0810 & & & & & $\begin{array}{l}-0.844 \\
(1.924)\end{array}$ & $\begin{array}{l}-2.101 \\
(1.661)\end{array}$ & \\
\hline DUR X D. CREDIT/GDP & & & & & & & $\begin{array}{l}-0.816^{* * *} \\
(0.198)\end{array}$ \\
\hline DUR X D. CREDIT/GDP X GFC0810 & & & & & & & $\begin{array}{l}0.641^{* *} \\
(0.266)\end{array}$ \\
\hline Observations & 66911 & 66911 & 61230 & 58903 & 66911 & 66911 & 66911 \\
\hline
\end{tabular}

extremely stable before the start of the global financial crisis, but declined dramatically (and in a statistically significant fashion on the source side) after 2007. Figure 1 thus clearly shows that our sample covers two distinct periods with very different external financing conditions.

The effects of SFD and DFD in normal and crisis times are not only statistically significant but also economically significant. Using the estimates given in column (2) and holding other factors constant, in the pre-crisis period, the relative volume of outward (inward) FDI in financially vulnerable sectors in a highly financially developed country like the United States was 37\% (48\%) larger than in a less financially developed country such as Italy. ${ }^{20}$ However, during the period 2008-2010, this positive gap between the two countries in terms of the relative volume of outward (inward) FDI in financially vulnerable sectors dropped to zero (33\%), leading the ratio of relative outward (inward) FDI in financially vulnerable sectors during the global financial crisis to the corresponding ratio during non-crisis years

\footnotetext{
${ }^{20}$ Relative outward FDI in financially vulnerable sectors is defined as the ratio of outward FDI in the Transportation Equipment sector (a typical high ED sector; $0.31 ; 75^{\text {th }}$ percentile of ED) to outward FDI in the Beverages sector (a typical low ED sector; $0.08 ; 25^{\text {th }}$ percentile of ED). The pre-sample private credit to GDP ratio for the United States is 1.70 and the pre-sample private credit to GDP ratio for Italy is 0.74 .
} 
Figure 1: Changes in the relative impact of financial development on FDI, period 2004-2010
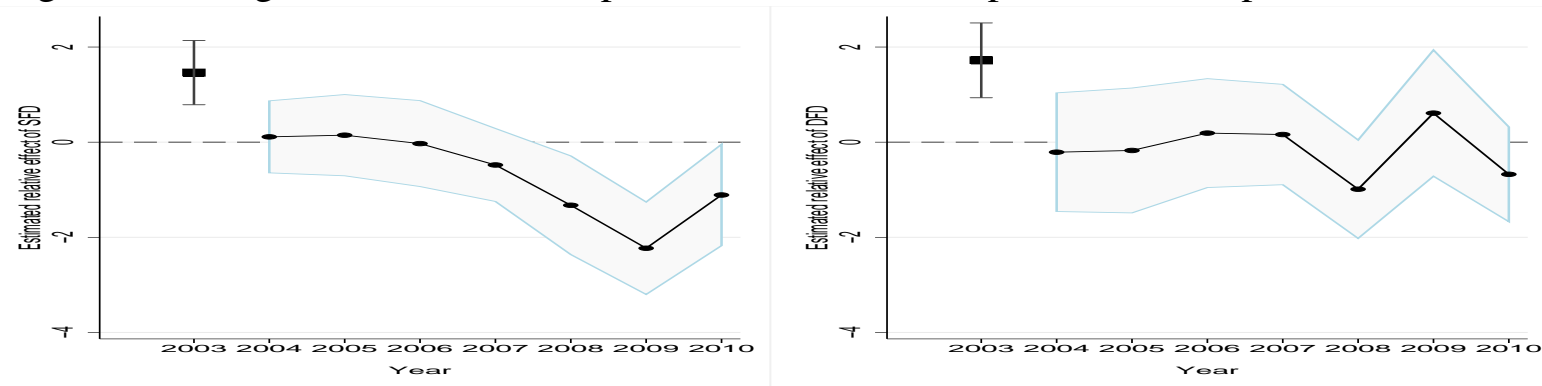

Note: squares indicate relative impacts of SFD and DFD in 2003 and dots indicate differences between the estimated effects of SFD and DFD in subsequent years relative their impacts in 2003. Capped spiked and shaded areas denote a 95\% confidence interval. Financially vulnerable sectors are defined here as sectors typically dependent on external finance.

to be about $27 \%(10 \%)$ lower in the highly financially developed country than in the less financially developed country.

The rest of Table 1 investigates the robustness of the baseline results displayed in column (2). In column (3), we omit the largest recipient of FDI in our sample (China; $21 \%$ of total FDI) and, in column (4), we omit the largest source of FDI in our sample (USA; 16\% of total FDI). In both columns, our results are qualitatively very similar to those of column (2), with the main difference that the triple interaction term involving DFD is statistically significant at the $10 \%$ level when we omit China. This may be because the high Chinese private credit to GDP ratio (pre-sample value of 1.089) does not provide an accurate picture of the availability of external finance for the private sector, as this ratio is believed to include credit to state-owned enterprises (Djankov et al., 2007).

In columns (5) and (6), we take into account that sectors not only vary in firms' reliance on external finance but also in firms' ability to access external finance. Raising outside finance is likely to be easier for firms in sectors characterized by a high level of tangible assets. In column (5), the interaction terms are now composed of our measure of asset tangibility, the TANG variable, the private credit to GDP ratio, and the GFC0810 variable; we follow other papers (Braun, 2003; Manova et al., 2011; Manova, 2013) by not inverting this measure such that a higher value corresponds to a lower tangibility of assets. 
Like in column (2), we find again that SFD and DFD increased the relative volume of FDI in financially vulnerable sectors in normal times, and that this effect of financial development strongly declined, and in a statistically significant manner for SFD, during the global financial crisis. In column (6), we include in the same regression the interactions terms involving the ED and TANG measures, capturing simultaneously the reliance of firms on external finance and their ability to raise outside finance. The coefficients on all simple interaction terms are statistically significant. In normal times, greater SFD and DFD disproportionately benefited FDI in sectors typically dependent on external finance and with low asset tangibility. However, among the coefficients on the triple interaction terms, only the one involving ED and SFD is statistically significant, although the coefficient on the triple interaction term involving TANG and SFD has the expected negative sign. This result suggests that the global financial crisis affected FDI by mainly reducing the relative availability of external finance in source countries, and to a much lower extent, by raising lending requirements. Such an argument is in line with the results of the survey of Chief Financial Officers carried out by Campello et al. (2010) during the global financial crisis in the U.S., Europe, and Asia. They show that the vast majority of firms 'somehow affected by credit constraints ${ }^{21}$ were able to obtain new lines of credit (or renew existing ones) but faced quantity and price constraints.

Some sectors are involved in the production of consumer final durable goods, i.e. tangible commodities purchased by consumers that can be used repeatedly and continuously over a period of three or more years. The purchase of some of these goods, e.g. a car, can require consumers to have access to external finance. Consequently, greater financial development could indirectly increase (vertical and horizontal) FDI in those sectors by expanding the effective demand in source and destination countries. On the other hand, demand for these goods may be perceived by lenders as more volatile than the demand for other goods because the purchase of durable goods tends be more sensitive to the state of the business

\footnotetext{
${ }^{21}$ This category is likely to encompass MNEs. These firms tend to be large and there is a negative link between financial constraints and firm size (Beck et al., 2005).
} 
cycle (Braun and Larrain, 2005). This means that lenders may be more reluctant to finance FDI projects involving the production of durable goods. Overall, if financially vulnerable sectors are also producers of durable goods, the effects of external financing conditions on financially vulnerable FDI in normal and crisis times may then be partly driven by how financial development influences the demand for durable goods and the ability and willingness of banks to fund projects with uncertain returns. We take this possibility into account in column (7), by including simple and triple interaction terms involving a sector-specific indicator of durable goods production (DUR). This binary measure, taken from Kroszner et al. (2007) is based on the classification of U.S. industries by the U.S. Bureau of Economic Analysis. Our baseline results are not qualitatively affected by the inclusion of these additional interaction terms. On the source side, the interactions terms involving DUR are statistically insignificant whereas the opposite is true on the destination side. The signs of the latter interaction terms suggest that, for a given level of DFD and sector-specific ED, it was harder to finance a FDI project in durable goods in normal times. However, this difference across sectors strongly diminished during the global financial crisis, possibly because the key constraint facing firms wishing to engage in FDI was first and foremost access to external finance.

In column (1) of Table 2, instead of examining whether our ED measure could be a proxy for other sector-specific characteristics, we investigate whether SFD and DFD are not proxies for other countryspecific characteristics which can influence FDI taking place in sectors deemed to be financially vulnerable. For example, financially vulnerable sectors may be sectors intensive in factors correlated with financial development and more broadly with economic development, such as human capital stock or institutional quality. We isolate the effects of financial development from overall economic development by including additional simple and triple interaction terms which involve the source and destination country-specific pre-sample values of the log of income per capita, average years of schooling in the population aged over 25, and a measure of institutional quality. Data on income per capita come from 
PWT 7.0 (Heston et al., 2011); data on human capital stock come from Barro and Lee (2010); the measure of institutional quality is the average size of three components of the Heritage Foundation's Index of Economic Freedom: Investment Freedom, Property Rights, Freedom from Corruption. ${ }^{22}$ Column (1) shows that the presence of these additional variables leave our baseline results qualitatively unchanged. ${ }^{23}$ In columns (2)-(5), we look at other measures of financial development. In columns (2) and (3), we use two other outcome-based measures of financial development, the pre-sample values of the stock market capitalization to GDP ratio (STMCAP/GDP) and of the private bond market capitalization to GDP ratio (BNDCAP/GDP). Data come from Beck et al. (2009) and are only available for a relatively small subset of the countries in the sample. Conceptually, while the private credit to GDP ratio and the private bond market capitalization to GDP ratio can be seen as capturing different aspects of external debt financing, the stock market capitalization to GDP ratio can be interpreted as reflecting external equity financing. The results of columns (2) and (3) suggest that firms mainly rely on external debt financing to finance their greenfield FDI, given that the coefficients on the interaction terms involving STMCAP/GDP tend to be statistically insignificant, whereas the coefficients on the interaction terms involving BCAP/GDP mirror those found when using CREDIT/GDP: they are large, have the expected sign, and are all statistically significant besides the coefficient on the triple interaction term involving DFD. ${ }^{24}$ In column (4), we replace our preferred outcome-based measure of financial development by a time-invariant institution-based measure of financial development (FIN_INST). This measure has been previously defined. Our results are qualitatively similar to those obtained with pre-sample private credit

\footnotetext{
${ }^{22}$ Coefficients on the additional interaction terms are not reported but they are available upon request to the authors.

${ }^{23}$ In an unreported regression, we also adopted an instrumental variables approach. In line with the rest of the literature, e.g. Rajan and Zingales (1998) and Kroszner et al. (2007), we used legal origin dummy variables as instruments for financial development. Our results are robust to this approach. However, doubts have been raised about the validity of using legal origin dummy variables as exogenous instruments for financial development (Manova, 2013). Hence, these results should be interpreted as simply showing that our findings are robust to a common instrumental variables strategy in the Finance and Growth literature.

${ }^{24}$ This result is in line with the small share of equity finance in total external funds used by firms in major OECD countries to finance physical investment, as calculated by Hackethal and Schmidt-Reinhard (2004). It is possible that our results would have been different if we had investigated the determinants of M\&A FDI, given a more frequent use of equity to finance deals (Di Giovanni, 2005).
} 
Table 2: Other country characteristics, alternative measures of financial development, and output shocks

\begin{tabular}{|c|c|c|c|c|c|c|c|}
\hline & \multicolumn{7}{|c|}{ Volume of bilateral FDI, by sector } \\
\hline & $\begin{array}{c}\text { Interactions with } \\
\text { other country } \\
\text { characteristics } \\
(1)\end{array}$ & $\begin{array}{c}\text { Stock market } \\
\text { capitalization } \\
\text { (2) }\end{array}$ & $\begin{array}{l}\text { Private bond } \\
\text { capitalization } \\
\text { (3) }\end{array}$ & $\begin{array}{l}\text { Financial } \\
\text { institutions } \\
\text { (4) }\end{array}$ & $\begin{array}{l}\text { Foreign } \\
\text { loans } \\
\text { (5) }\end{array}$ & $\begin{array}{l}\text { Smaller } \\
\text { VA } \\
\text { sample } \\
(6)\end{array}$ & $\begin{array}{c}\text { Inclusion } \\
\text { VA } \\
\text { terms } \\
(7)\end{array}$ \\
\hline ED X S. CREDIT/GDP & $\begin{array}{l}1.253^{* * *} \\
(0.409)\end{array}$ & & & & $\begin{array}{l}1.500^{* * *} \\
(0.322)\end{array}$ & $\begin{array}{l}1.556^{* * *} \\
(0.398)\end{array}$ & $\begin{array}{l}1.208^{* * *} \\
(0.363)\end{array}$ \\
\hline ED X S. CREDIT/GDP X GFC0810 & $\begin{array}{l}-1.581^{* * *} \\
(0.492)\end{array}$ & & & & $\begin{array}{l}-1.425^{* * *} \\
(0.454)\end{array}$ & $\begin{array}{l}-2.573^{* * *} \\
(0.725)\end{array}$ & $\begin{array}{l}-2.779^{* * *} \\
(0.728)\end{array}$ \\
\hline ED X S. STMCAP/GDP & & $\begin{array}{l}0.084 \\
(0.405)\end{array}$ & & & & & \\
\hline ED X S. STMCAP/GDP X GFC0810 & & $\begin{array}{l}-0.670 \\
(0.643)\end{array}$ & & & & & \\
\hline ED X S. BNDCAP/GDP & & & $\begin{array}{l}3.422 * * * \\
(0.660)\end{array}$ & & & & \\
\hline ED X S. BNDCAP/GDP X GFC0810 & & & $\begin{array}{l}-3.447^{* * *} \\
(0.901)\end{array}$ & & & & \\
\hline ED X S. FIN_INST & & & & $\begin{array}{l}0.146^{* *} \\
(0.070)\end{array}$ & & & \\
\hline ED X S. FIN_INST X GFC0810 & & & & $-0.150^{* *}$ & & & \\
\hline ED X S. In(FOR_LOANS/GDP) & & & & & $\begin{array}{l}-0.362 \\
(0.229)\end{array}$ & & \\
\hline ED X S. In(FOR_LOANS/GDP) X GFC0810 & & & & & $\begin{array}{l}0.075 \\
(0.241)\end{array}$ & & \\
\hline ED X D. CREDIT/GDP & $\begin{array}{l}1.445^{* * *} \\
(0.350)\end{array}$ & & & & $\begin{array}{l}1.723^{* * *} \\
(0.343)\end{array}$ & $\begin{array}{l}1.680^{* * *} \\
(0.415)\end{array}$ & $\begin{array}{l}1.098^{* * *} \\
(0.405)\end{array}$ \\
\hline ED X D. CREDIT/GDP X GFC0810 & $\begin{array}{l}-0.393 \\
(0.527)\end{array}$ & & & & $\begin{array}{l}-0.377 \\
(0.460)\end{array}$ & $\begin{array}{l}-1.813^{* * *} \\
(0.620)\end{array}$ & $\begin{array}{l}-1.633^{* *} \\
(0.644)\end{array}$ \\
\hline ED X D. STMCAP/GDP & & $\begin{array}{l}1.346^{* * *} \\
(0.421)\end{array}$ & & & & & \\
\hline ED X D. STMCAP/GDP X GFC0810 & & $\begin{array}{l}-0.690 \\
(0.501)\end{array}$ & & & & & \\
\hline ED X D. BNDCAP/GDP & & & $\begin{array}{l}1.898^{* * *} \\
(0.660)\end{array}$ & & & & \\
\hline ED X D. BNDCAP/GDP X GFC0810 & & & $\begin{array}{l}-1.040 \\
(0.801)\end{array}$ & & & & \\
\hline ED X D. FIN_INST & & & & $\begin{array}{l}0.171^{* * *} \\
(0.053)\end{array}$ & & & \\
\hline ED X D. FIN_INST X GFC0810 & & & & $\begin{array}{l}-0.112^{*} \\
(0.066)\end{array}$ & & & \\
\hline ED X D. $\ln ($ FOR_LOANS/GDP) & & & & & $\begin{array}{l}-0.011 \\
(0.166)\end{array}$ & & \\
\hline ED X D. $\ln ($ FOR_LOANS/GDP) X GFC0810 & & & & & $\begin{array}{l}-0.217 \\
(0.194)\end{array}$ & & \\
\hline S. $\ln$ (VALUE ADDED) & & & & & & & $\begin{array}{l}0.784^{* * *} \\
(0.123)\end{array}$ \\
\hline D. $\ln ($ VALUE ADDED) & & & & & & & $\begin{array}{l}0.692^{* * *} \\
(0.100)\end{array}$ \\
\hline
\end{tabular}

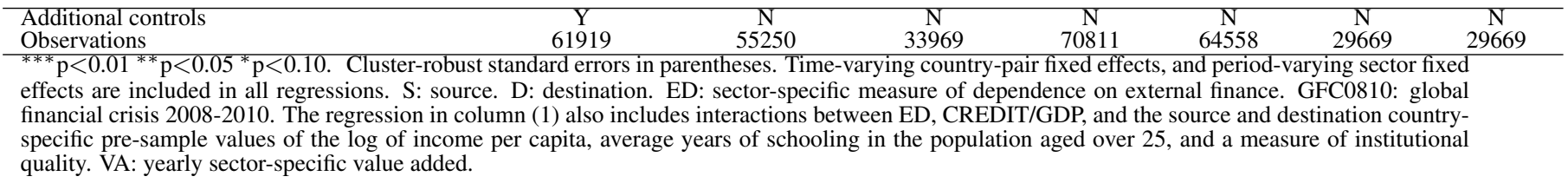

to GDP ratio: in normal times, SFD and DFD have a positive effect on the relative volume of bilateral

FDI in financially vulnerable sectors and this effect strongly declines in times of credit crisis, especially

on the source country side. However, a key difference with our previous results is that we now find that

the tightening of credit conditions in destination countries during the global financial crisis also had a

statistically significant negative impact on FDI. ${ }^{25}$ In column (5), by including interaction terms with the

\footnotetext{
${ }^{25}$ Using the estimates given in column (3) and holding other factors constant, in the pre-crisis period, the relative volume of outward (inward) FDI in financially vulnerable sectors in a highly financially developed country like the United States (score of 15) was 22\% (27\%) larger than in a less financially developed country such as Italy (score of 9). However, during the period 2008-2010, this positive gap between the two countries in terms of the relative volume of outward (inward) FDI
} 
pre-sample outstanding amount of international loans from banks not resident in a given source or destination country to GDP ( $\ln ($ FOR_LOANS/GDP)), we take into account that firms can obtain credit from foreign sources directly. Coefficients on these additional interaction terms are not statistically significant suggesting that firms borrow mainly from local financial intermediaries in source and destination countries.

In columns (6)-(7), we investigate how the effects of SFD and DFD that we are estimating change when controlling for sector-specific activity and output shocks. Higher financial development is likely to increase the number and size of active producers, especially in financially vulnerable sectors (Rajan and Zingales, 1998). Holding other factors constant, a larger sector can thus be expected to be associated with larger outward FDI flows, and, possibly, larger inward flows if, for example, strong agglomeration effects operate. Column (6) presents our estimates using the sample for which we have yearly data on sector-specific value added. Estimates are qualitatively close to our baseline results with the key difference that the coefficient on the triple interaction term involving DFD is statistically significant at the $1 \%$ level in this sample. In column (7), we include sector-specific value added; data come from UNIDO. On both source and destination sides, the VA terms are statistically significant at the $1 \%$ level, indicating that 'larger' sectors are associated with larger bilateral FDI flows. This can be the outcome of a larger number of producers, higher average firm-scale, or greater agglomeration externalities. Relative to column (6), the inclusion of the measures of sector-specific activity tends to reduce mainly the size of the coefficients on the simple interaction terms, which nevertheless remain large (65-78\% of the initial size), positive, and statistically significant at the $1 \%$ level. This outcome suggests that SFD and DFD have, in normal times, general and FDI-specific effects on FDI. ${ }^{26}$ Higher financial development increases FDI by raising sector-specific scale and allowing firms to finance their foreign investment, especially in in financially vulnerable sectors dropped to about zero (8\%), leading the ratio of relative outward (inward) FDI in financially vulnerable sectors during the global financial crisis to the same ratio during non-crisis years to be about 19\% (14\%) lower in the highly financially developed country than in the less financially developed country.

${ }^{26}$ A qualitatively similar result is found by Manova (2013) in the context of international trade: $20-25 \%$ of the total effect of higher SFD on exports is driven by financial development-induced changes in sector-specific output. 
financially vulnerable sectors. On the other hand, the coefficients on the triple interaction terms remain as large or become larger than in column (5), implying that the global financial crisis did not affect FDI through a negative effect on sector-specific output, operating for example through a reduction in the availability of internal finance.

\section{Credit channel effect of the global financial crisis}

In Table 3, we deepen our focus on the credit channel effect of the global financial crisis on FDI. In column (1) we control for the fact that FDI in ED sectors may be more sensitive to the state of the business cycle than FDI in other sectors. As suggested by Braun and Larrain (2005), the investment of firms in financially vulnerable sectors is more likely to be influenced by current cash flows, which are a positive function of economic growth, than the investment of firms in other sectors. In addition, if the customers of firms in these financially vulnerable are themselves financially vulnerable, the attractiveness for firms in financially vulnerable sectors to engage in a vertical (efficiency-seeking) or horizontal (market-seeking) FDI to serve customers at home or abroad can also be a positive function of economic growth. Given that in the early part of the last decade, high financial development has often been correlated with strong debt-driven economic growth, which abruptly ended during the global financial crisis, it is possible that the coefficients on the interaction terms capture in fact how changes in demand influence both the ability and willingness of firms to engage in FDI. To consider this possibility, we include in our econometric model, all the possible interactions between source or destination GDP growth, the sectorspecific external dependence measure, the global financial crisis dummy variable, and also with SFD or DFD. We include 'growth' interaction terms involving financial development because any change in access to external finance due the balance sheets effects induced by changes in internal finance should be milder in more financially developed countries (Braun and Larrain, 2005). We also take into account that a few countries in our sample have experienced banking crises in the past (Argentina, Dominican Republic, and Uruguay) by interacting the interaction term between country-specific financial devel- 
opment and sector-specific financial vulnerability with a dummy variable (BCRIS_pre08_t) taking the value of one during the years a country experienced a banking crisis before 2008. Lastly, we also control for sector-specific effects of currency crises and sovereign debt crises, as well as their interactions with SFD and DFD. ${ }^{27}$ Column (1) shows that the additional 'non-banking' variables have little qualitative effect on our results. Hence, our results do not appear to be ultimately driven by changes in the expected demand for the output produced by financially vulnerable sectors or the effects of non-banking crises. On the other hand, the coefficient on the triple interaction term involving SFD and pre-2008 banking crises (BCRIS_pre08_t) is very large, negative, and statistically significant. This result is consistent with our findings related to the global financial crisis.

In column (2), as well as in columns (3)-(9) of Table 3, instead of trying to correct for an omitted variable bias related to the omission of relevant variables correlated with sector-specific external dependence or country-specific financial development, we estimate econometric models in which we include sector-country-pair fixed effects, in addition to various time-varying sector fixed effects, including those related to country-specific GDP growth, and period-varying country fixed effects. A key advantage of this approach is that we can assume with more confidence that the effects that we estimate are causal. However, because we rely on changes within sector-country-pair to identify the parameters of interest, we cannot estimate anymore the effects of SFD and DFD on the relative volume of FDI in financially vulnerable sectors in normal times. We find again that the coefficient on the triple interaction term involving SFD is negative, large, and statistically significant. This coefficient, which is close to our baseline estimate, suggests that our previous econometric models did not omit a relevant variable.

The global nature of the global financial crisis should not hide the fact that the financial systems of some countries were more disrupted than those of other countries during the period 2008-2010. For example, some countries experienced banking crises. We incorporate this differential impact in our model

\footnotetext{
${ }^{27}$ Data on the occurrence of these crises come from Reinhart and Rogoff (2010). Coefficients on the additional interaction terms are not reported but they are available upon request to the authors.
} 
Table 3: Degree of tightening of credit conditions during the global financial crisis

\begin{tabular}{|c|c|c|c|c|c|c|c|c|c|c|}
\hline & \multirow{3}{*}{$\begin{array}{l}\text { Inter. } \\
\text { S. \& D. } \\
\text { GDPG } \\
(1)\end{array}$} & \multirow{3}{*}{$\begin{array}{l}\text { Sector- } \\
\text { count.-pair } \\
\text { effects (+) } \\
\text { (2) }\end{array}$} & \multirow{3}{*}{ 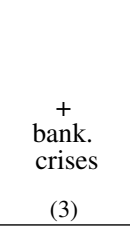 } & \multicolumn{4}{|c|}{ Volume of bilateral FDI, by sector } & + & + & \multirow[b]{2}{*}{$\begin{array}{l}\text { count.-pair } \\
\text { effects } \\
\text { ditions }\end{array}$} \\
\hline & & & & 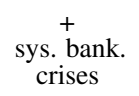 & $\underset{\substack{+ \\
\text { VAmple }}}{+}$ & $\begin{array}{c}+ \\
\text { inclusion } \\
\text { VA }\end{array}$ & $\begin{array}{l}\stackrel{+}{+} \\
\text { alt. bank. } \\
\text { crises }\end{array}$ & \multicolumn{2}{|c|}{ Change credit conditions } & \\
\hline & & & & (4) & (5) & (6) & $(7)$ & $(8)$ & (9) & (10) \\
\hline ED X S. CREDIT/GDP & $\begin{array}{l}1.586^{* *} \\
(0.716)\end{array}$ & & & & & & & & & $\begin{array}{l}1.041^{* * *} \\
(0.349)\end{array}$ \\
\hline (...) X GFC0810 & $\begin{array}{l}-2.713^{* * *} \\
(0.911)\end{array}$ & $\begin{array}{l}-1.196^{* * *} \\
(0.359)\end{array}$ & $\begin{array}{l}-0.727^{*} \\
(0.381)\end{array}$ & $\begin{array}{l}-0.884^{* * *} \\
(0.339)\end{array}$ & $\begin{array}{l}-0.921^{*} \\
(0.517)\end{array}$ & $\begin{array}{l}-0.916^{*} \\
(0.517)\end{array}$ & $\begin{array}{l}3.036^{* *} \\
(1.518)\end{array}$ & & & \\
\hline (...) X S. BCRIS_pre08_t & $\begin{array}{l}-26.082^{*} \\
(10.035)\end{array}$ & & & & & & & & & \\
\hline (...) X S. BCRIS & & & $\begin{array}{l}-1.842^{* * *} \\
(0.693)\end{array}$ & & $\begin{array}{l}-2.228^{*} \\
(1.209)\end{array}$ & $\begin{array}{l}-2.211^{*} \\
(1.215)\end{array}$ & & & & \\
\hline (...)X S. SYS_BCRIS & & & & $\begin{array}{l}-1.964^{* *} \\
(0.921)\end{array}$ & & & & & & \\
\hline (...) X S. ALT_BCRIS & & & & & & & $\begin{array}{l}-4.734^{* * *} \\
(1.553)\end{array}$ & & & \\
\hline (...) X S. CH_CRED & & & & & & & & $\begin{array}{l}0.062^{* * *} \\
(0.018)\end{array}$ & $\begin{array}{l}0.065^{* * *} \\
(0.018)\end{array}$ & $\begin{array}{l}0.038^{* *} \\
(0.018)\end{array}$ \\
\hline (...) X S. CH_CRED X POS. & & & & & & & & & $\begin{array}{l}0.069 \\
(0.183)\end{array}$ & \\
\hline ED X D. CREDIT/GDP & $\begin{array}{l}1.455^{*} \\
(0.751)\end{array}$ & & & & & & & & & $\begin{array}{l}1.754^{* * *} \\
(0.293)\end{array}$ \\
\hline (...) X GFC0810 & $\begin{array}{l}-0.899 \\
(0.902)\end{array}$ & $\begin{array}{l}-0.340 \\
(0.398)\end{array}$ & $\begin{array}{l}-0.191 \\
(0.483)\end{array}$ & $\begin{array}{l}0.093 \\
(0.445)\end{array}$ & $\begin{array}{l}-1.489 \\
(0.958)\end{array}$ & $\begin{array}{l}-1.453 \\
(0.960)\end{array}$ & $\begin{array}{l}0.565 \\
(0.725)\end{array}$ & & & \\
\hline (...) X D. BCRISpre08_t & $\begin{array}{l}4.896 \\
(12.137)\end{array}$ & & & & & & & & & \\
\hline (...) X D. BCRIS & & & $\begin{array}{l}-0.201 \\
(0.799)\end{array}$ & & $\begin{array}{l}-1.105 \\
(1.573)\end{array}$ & $\begin{array}{l}-1.203 \\
(1.575)\end{array}$ & & & & \\
\hline (...) X D. SYS_BCRIS & & & & $\begin{array}{l}-2.333^{* *} \\
(1.115)\end{array}$ & & & & & & \\
\hline (...) X D. ALT_BCRIS & & & & & & & $\begin{array}{l}-1.479^{*} \\
(0.895)\end{array}$ & & & \\
\hline (...) X D. CH_CRED & & & & & & & & $\begin{array}{l}0.007 \\
(0.023)\end{array}$ & $\begin{array}{l}0.015 \\
(0.026)\end{array}$ & $\begin{array}{l}0.039^{* *} \\
(0.016)\end{array}$ \\
\hline (...) X D. CH_CRED X POS. & & & & & & & & & $\begin{array}{l}-0.082 \\
(0.078)\end{array}$ & \\
\hline S. $\ln$ (VALUE ADDED) & & & & & & $\begin{array}{l}0.321 \\
(0.595)\end{array}$ & & & & \\
\hline D. $\ln$ (VALUE ADDED) & & & & & & $\begin{array}{l}0.280 \\
(0.182)\end{array}$ & & & & \\
\hline $\begin{array}{l}\text { Additional controls } \\
\text { Observations }\end{array}$ & $\begin{array}{c}\mathrm{Y} \\
44083\end{array}$ & $\begin{array}{r}\mathrm{Y} \\
41344\end{array}$ & $\begin{array}{r}\mathrm{Y} \\
41344\end{array}$ & $\mathrm{Y}$ & $\begin{array}{c}\mathrm{Y} \\
15596\end{array}$ & $\begin{array}{c}\mathrm{Y} \\
15596\end{array}$ & $\begin{array}{c}\mathrm{Y} \\
31168\end{array}$ & $\begin{array}{c}\mathrm{Y} \\
40089\end{array}$ & $\begin{array}{c}\mathrm{Y} \\
40089\end{array}$ & $\begin{array}{c}\mathrm{Y} \\
65078\end{array}$ \\
\hline
\end{tabular}

by interacting the triple interaction terms with a banking crisis dummy variable, previously defined in section 3.4 (BCRIS). Column (3) shows that the coefficients on the two interaction terms involving SFD are large, negative, and statistically significant. The estimates imply that the ratio of relative outward FDI in financially vulnerable sectors during the global financial crisis to relative outward FDI in financially vulnerable sectors during non-crisis years was about $42 \%$ lower in a highly financially developed country experiencing a banking crisis like the United States than in a less financially developed country not experiencing a banking crisis such as Italy, i.e. a 27 percentage points fall relative to a situation where the highly financially developed country did not experience a banking crisis. On the other hand, we still do not find evidence of tighter credit conditions on destination side. In column (4), we focus 
on systemic crises only (SYS_BCRIS). Results are very similar to those of column (3), except that we now find that the differential negative effect of systematic banking crises on both outward and inward FDI are statistically significantly different and larger than the differential negative average effect of the other crises experienced by source and destination countries. In column (6), we control for sectorspecific value added. Our results qualitatively hold and a comparison between the estimates of column (6) and column (5), where we use the same sample but do not include the value added terms, shows that controlling for sector-specific output has no impact on the coefficients on the triple interaction terms.

In column (7), we use the alternative measure of significant financial distress in the banking system, based on the joint observation of negative output growth and deceleration of private credit growth (ALT_BCRIS). This variable was previously defined in section 3.4. We find again that relative outward FDI flows in financially vulnerable sectors originating from countries experiencing a banking crisis have been significantly more affected, in economic and statistical terms, than those originating from similar countries not experiencing a banking crisis. Relative to other columns of Table 3, this finding also holds for inward FDI in countries experiencing a banking crisis. A second difference is that we now find that relative outward FDI flows in financially vulnerable sectors originating from countries not experiencing a banking crisis have grown larger during the global financial crisis, holding other factors constant. This surprising result suggests that some countries have experienced a loosening of credit conditions during the global financial crisis instead of a tightening of credit conditions.

We investigate this issue more closely in columns (8)-(10) by using, as indicator of the severity of credit conditions during the global financial crisis, the relative change in how firms perceive ease of access to external finance (CH_CRED). This variable was previously defined in section 3.4. We find that the relative volume of outward FDI in financially vulnerable sectors in more financially developed countries responded differently to the global financial crisis according to how credit conditions changed in source countries during the period 2008-2010. The estimates imply that the ratio of relative outward FDI 
in financially vulnerable sectors during the global financial crisis to relative outward FDI in financially vulnerable sectors during non-crisis years was about $16 \%$ lower (18\% higher) in a highly financially developed country experiencing a $13 \%$ drop (rise) in ease of access to credit during the global financial crisis than in a less financially developed country subject to the same shock. In column (9), we investigate whether we can assume that symmetry of impacts between the tightening and the loosening of credit conditions holds by interacting the interactions terms involving CH_CRED with a dummy variable taking the value of one if the change is positive (POS.). The coefficients on these interaction terms are not statistically significant suggesting that indeed better external financing conditions have been associated with a rise in the relative volume of FDI in financially vulnerable sectors. This symmetry of outcomes supports our previous findings, at least on the source side, that higher financial development is associated with a greater relative volume of FDI in financially vulnerable sectors in normal times. Finally, in column (10), by replacing time-invariant sector-country-pair fixed effects with time-varying countrypair fixed effects, we investigate which results we obtain if we exploit both the between industry-country dimension and the within industry-country dimension of the data. In other words, we do not look only at what happened to FDI in a given sector over time but also at what happened to FDI in this sector relative to what happened to FDI in other sectors at a given point of time. When we do so, the coefficients on all interaction terms, including those involving DFD, are large, statistically significant, and have the expected sign. A potential explanation for the difference in results between columns (9) and (10) is that firms engaged in FDI in a given destination country before the global financial crisis, generating a positive flow in a given sector-country-pair, may have had preferential access to external finance during the crisis, for example due to the existence of previously established lines of credit.

\section{Margins of FDI}

We end this section by exploring in Table 4 the impact of the global financial crisis on the extensive and intensive margins of FDI. In all columns, we control for the log of source and destination GDP, as 
well as their interactions with the ED measure. In columns (1)-(3), for comparison purpose, we report our main previous findings using the volume of bilateral FDI as dependent variable. In columns (4)-(6), we use as dependent variable, the number of bilateral FDI projects (the 'extensive margin'). Columns (4)-(6) show that, in normal times, SFD and DFD have a large, positive, and statistically significant effect on the relative number of bilateral projects in financially vulnerable sectors. ${ }^{28}$ However, we do not find that the relative number of bilateral projects fell statistically significantly during the global financial crisis. On the source side, the coefficient on the triple interaction term is negative but not statistically significant, and on the destination side, the coefficient on the interaction term has a sign opposite to our expectations and is statistically significant in column (4). On the other hand, columns (7)-(9) show that when we use the average value of the FDI projects (the 'intensive margin'), our results are typically in line with our previous findings. ${ }^{29}$ Furthermore, we now find evidence for a role played by tighter credit conditions in destination countries during the global financial crisis, as the coefficients on the triple interaction terms involving DFD have the expected negative signs and are statistically significant in columns (7)-(9)..$^{30}$

Overall, the results of Table 4 suggest that financial development influences both margins of FDI in normal times, and that MNEs have responded to the lack of access to external finance during the global financial crisis by decreasing the size of their foreign projects instead of undertaking fewer projects, holding other factors constant. On the source side, during the global finance crisis, firms in financially

\footnotetext{
${ }^{28}$ Using the estimates given in column (4) and holding other factors constant, in the pre-crisis period, the relative number of outward (inward) projects in financially vulnerable sectors in a highly financially developed country like the United States was $17 \%(11 \%)$ larger than in a less financially developed country such as Italy.

${ }^{29}$ It is important to note that modelling the average size of the cross-border investments conditional on positive FDI does not result in a sample selection issue. Given that we are interested in how the global financial crisis influences average project size when FDI occurs, the observations for which outward FDI is positive form an appropriate subsample of the population of interest (Wooldridge, 2010).

${ }^{30}$ Using the estimates given in column (7) and holding other factors constant, in the pre-crisis period, the average value of outward (inward) FDI in financially vulnerable sectors in a highly financially developed country like the United States was $21 \%$ (33\%) larger than in a less financially developed country. However, during the period 2008-2010, this positive gap between the two countries in terms of the relative volume of outward (inward) FDI in financially vulnerable sectors dropped to $0 \%$, leading the ratio of relative outward (inward) average value of FDI projects in financially vulnerable sectors during the global financial crisis to the same ratio during non-crisis years to be about $21 \%(21 \%)$ lower in the highly financially developed country than in the less financially developed country.
} 
Table 4: Financial development and margins of FDI

\begin{tabular}{|c|c|c|c|c|c|c|c|c|c|}
\hline & \multicolumn{9}{|c|}{ Bilateral FDI, by sector } \\
\hline & \multicolumn{3}{|c|}{ Volume } & \multicolumn{3}{|c|}{$\begin{array}{c}\text { Number of } \\
\text { projects }\end{array}$} & \multicolumn{3}{|c|}{$\begin{array}{c}\text { Average } \\
\text { size }\end{array}$} \\
\hline & $\begin{array}{l}\text { count.-pair } \\
\text { effects } \\
\text { (1) }\end{array}$ & $\begin{array}{l}\text { Change } \\
\text { credit } \\
\text { cond. } \\
(2)\end{array}$ & $\begin{array}{l}\text { + Sector- } \\
\text { count.-pair } \\
\text { effects } \\
(3)\end{array}$ & $\begin{array}{l}\text { count.-pair } \\
\text { effects } \\
(4)\end{array}$ & $\begin{array}{l}\text { Change } \\
\text { credit } \\
\text { cond. } \\
(5)\end{array}$ & $\begin{array}{l}\text { + Sector- } \\
\text { count.-pair } \\
\text { effects } \\
(6)\end{array}$ & $\begin{array}{l}\text { count.-pair } \\
\text { effects } \\
(7)\end{array}$ & $\begin{array}{l}\text { Change } \\
\text { credit } \\
\text { cond. } \\
(8)\end{array}$ & $\begin{array}{l}\text { + Sector- } \\
\text { count.-pair } \\
\text { effects } \\
(9)\end{array}$ \\
\hline ED X S. CREDIT/GDP & \multirow{3}{*}{$\begin{array}{l}1.405^{* * *} \\
(0.337) \\
-1.450^{* * *} \\
(0.481)\end{array}$} & $\begin{array}{l}1.041^{* * *} \\
(0349)\end{array}$ & & $0.703^{* * *}$ & \multirow{2}{*}{\multicolumn{2}{|c|}{$\begin{array}{l}0.697^{* * *} \\
(0.098)\end{array}$}} & \multirow{3}{*}{$\begin{array}{l}0.891^{* * *} \\
(0.307) \\
-1.047^{* *} \\
(0.461)\end{array}$} & $0.759^{* *}$ & \\
\hline (...) X GFC0810 & & (0.34) & & $\begin{array}{l}-0.106 \\
-0.206 \\
(0.148)\end{array}$ & & & & & \\
\hline (...) X GFC0810 X S. CH_CRED & & $\begin{array}{l}0.038^{* *} \\
(0.018)\end{array}$ & $\begin{array}{l}0.062^{* * *} \\
(0.018)\end{array}$ & & $\begin{array}{l}0.012 \\
(0.007)\end{array}$ & $\begin{array}{l}0.006 \\
(0.009)\end{array}$ & & $\begin{array}{l}0.048^{* * *} \\
(0.015)\end{array}$ & $\begin{array}{l}0.037^{*} \\
(0.020)\end{array}$ \\
\hline ED X D. CREDIT/GDP & \multirow{3}{*}{$\begin{array}{l}1.797^{* * *} \\
(0.347) \\
-0.496 \\
(0.445)\end{array}$} & $\begin{array}{l}1.754^{* * *} \\
(0.293)\end{array}$ & & $\begin{array}{l}0.473^{* * *} \\
(0.100)\end{array}$ & $\begin{array}{l}0.570^{* * *} \\
(0.091)\end{array}$ & & \multirow{3}{*}{$\begin{array}{l}1.277^{* * *} \\
(0.356) \\
-1.084^{* *} \\
(0.450)\end{array}$} & $\begin{array}{l}1.095^{* * *} \\
(0.305)\end{array}$ & \\
\hline (...) X GFC0810 & & & & $\begin{array}{l}0.267^{* *} \\
(0.119)\end{array}$ & & & & & \\
\hline (...) X GFC0810 X D. CH_CRED & & $\begin{array}{l}0.039^{* *} \\
(0.016)\end{array}$ & $\begin{array}{l}0.007 \\
(0.023)\end{array}$ & & $\begin{array}{l}0.007 \\
(0.006)\end{array}$ & $\begin{array}{l}-0.008 \\
(0.007)\end{array}$ & & $\begin{array}{l}0.059^{* *} \\
(0.024)\end{array}$ & $\begin{array}{l}0.064^{* *} \\
(0.030)\end{array}$ \\
\hline Additional controls & $\mathrm{Y}$ & $\mathrm{Y}$ & $\mathrm{Y}$ & $\mathrm{Y}$ & $\mathrm{Y}$ & $\mathrm{Y}$ & $\mathrm{Y}$ & $\mathrm{Y}$ & $\mathrm{Y}$ \\
\hline Observations & 66820 & 65078 & 40089 & 66820 & 65078 & 40089 & 6226 & 6184 & 6187 \\
\hline
\end{tabular}

developed countries appear to have still been able to gain greater access to external finance than those in less financially developed countries, allowing them to initiate FDI projects. However, lower amount of credit available are likely to have forced them to reduce the scale of their FDI projects relative to normal times. As previously discussed, such an argument is in line with the results of the international survey of Chief Financial Officers carried out by Campello et al. (2010) during the global financial crisis. The category of firms to which MNEs presumably belong (i.e. 'somewhat affected' firms by credit constraints) could still raise new external finance but in lower quantity and/or at a higher price.

On the destination side, the fact that we find, notably in column (4), evidence that the relative number of inward projects in financially vulnerable sectors has increased in more financially developed countries helps to explain why we often obtained a negative but statistically insignificant coefficient on the triple interaction term involving DFD. Such a surprising result may find its roots in opportunistic FDI driven by crisis-induced opportunities. Krugman (2000) and Aghion et al. (2004) discuss how foreign investors can be attracted by the temporary depressed price of an asset or a factor of production in countries undergoing an economic and financial crisis while other studies suggest that the opportunities that crises create for FDI take the form of weaker domestic competition (Hawkins and Macaluso, 1977; Desai et al., 
2008). However, as shown in columns (7)-(9), the extent of this bargain-hunting behaviour appears to have been constrained by the availability of external finance in destination countries. Indeed, the dominance of the negative effect on the intensive margin of FDI of tighter credit conditions in destination countries has been visible in many of our regressions, where the coefficient on the triple interaction term involving DFD was not only negative, large, but also statistically significant.

Before ending this section, it is important to emphasise that our results are likely to be generalizable to the effects of external financing conditions on aggregate manufacturing greenfield FDI, despite our focus on the differential effects of financial development across manufacturing sectors varying in their financial vulnerability. As previously indicated, most sectors exhibit a positive (84\% of them) and large dependence on external finance (ED $\geq 0.19$ for $60 \%$ of them). Furthermore, in the top 15 source (destination) countries of FDI before 2008, 73\% (81\%) of the FDI flows were in sectors with ED $\geq$ $0.19 \%$. Hence, given the structural dependence of most manufacturing sectors on external finance and the large concentration of FDI activities in sectors heavily dependent on external finance, it is very likely that external financing conditions strongly influence aggregate manufacturing greenfield FDI. A final point is that we have often found that the economic effect of DFD on the relative volume of FDI in financially vulnerable sectors is larger than the effect of SFD on the relative volume of FDI. However, in our results, the differences in these coefficients are not statistically significant. For example, in column (1) of Table 4, the estimated difference between the coefficients on the interaction terms involving DFD and SFD is 0.39 with a standard error of 0.52 ( $p$-value=0.46). Hence, our overall conclusion is that DFD matters as much as SFD in terms of promoting FDI. 


\section{Conclusion}

We showed in this paper that external financing conditions in source and destination countries are likely to be important determinants of FDI. We find robust evidence that greater financial development has a positive influence on outward and inward greenfield FDI in normal times and that the fall in greenfield FDI during the global financial crisis can be partly explained by the decline in the availability of external finance. This result complements those of the international trade literature on the effects of external financing conditions on trade. Our findings also provide some evidence on the worldwide nature of the credit constraints generated by the global financial crisis. Finally, they suggest that the superior financial advantage of MNEs is likely to be a function of the depth and stability of the financial system in their home country.

\section{References}

Aghion, P., Bacchetta, P., and Banerjee, A. (2004), Financial Development and the Instability of Open Economies, Journal of Monetary Economics 51, 1077-1106.

Alfaro, L. and Charlton, A. (2009), Intra-industry foreign direct investment, American Economic Review 99, 2096-2119.

Amiti, M. and Weinstein, D. E. (2011), Exports and Financial Shocks, The Quarterly Journal of Economics 126, 1841-1877.

Antras, P., Desai, M. A., and Foley, C. F. (2009), Multinational Firms, FDI Flows, and Imperfect Capital Markets, The Quarterly Journal of Economics 124, 1171-1219. 
Barro, R. J. and Lee, J.-W. (2010), A New Data Set of Educational Attainment in the World, 1950-2010, NBER Working Paper, No. 15902.

Beck, T. (2002) , Financial Development and International Trade: Is There a Link? Journal of International Economics 57, 107-131.

(2003) , Financial Dependence and International Trade, Review of International Economics $11,296-316$.

Beck, T., Demirguc-Kunt, A., and Levine, R. (2009), Financial Institutions and Markets Across Countries and Over Time - Data and Analysis, Policy Research Working Paper Series No. 4943.

Beck, T., Demirgüç-Kunt, A., and Maksimovic, V. (2005), Financial and Legal Constraints to Growth: Does Firm Size Matter? Journal of Finance 60, 137-177.

Berkmen, P. S., Gelos, G., Rennhack, R., and Walsh, J. P. (2012), The Global Financial Crisis: Explaining Cross-Country Differences in the Output Impact, Journal of International Money and Finance 31, $42-59$.

Bilir, L. K., Chor, D., and Manova, K. (2014), Host Country Financial Development and MNC Activity, mimeo; revised version, August 2014.

Braun, M. (2003) , Financial Contractibility and Assets' Hardness: Industrial Composition and Growth, mimeo, University of California Los Angeles.

Braun, M. and Larrain, B. (2005), Finance and the Business Cycle: International, Inter-Industry Evidence, Journal of Finance 60, 1097-1128.

Bricongne, J.-C., Fontagné, L., Gaulier, G., Taglioni, D., and Vicard, V. (2012), Firms and the Global Crisis: French Exports in the Turmoil, Journal of International Economics 87, 134-146.

Broner, F., Didier, T., Erce, A., and Schmukler, S. L. (2013), Gross Capital Flows: Dynamics and Crises, Journal of Monetary Economics 60, 113-133. 
Campello, M., Graham, J. R., and Harvey, C. R. (2010), The Real Effects of Financial Constraints: Evidence From a Financial Crisis, Journal of Financial Economics 97, 470-487.

Cetorelli, N. and Goldberg, L. S. (2010), Global Banks and International Shock Transmission: Evidence From the Crisis, IMF Economic Review 59, 41-76.

Chor, D. and Manova, K. (2012), Off the Cliff and Back? Credit Conditions and International Trade during the Global Financial Crisis, Journal of International Economics 87, 117-133.

Davies, R. B., Desbordes, R., and Ray, A. (2015), Greenfield versus Merger \& Acquisition FDI: Same Wine, Different Bottles?

Desai, M. A., Foley, C. F., and Forbes, K. J. (2008), Financial Constraints and Growth: Multinational and Local Firm Responses to Currency Depreciations, Review of Financial Studies 21, 2857-2888.

Desai, M. A., Foley, C. F., and Hines, J. R. (2006), Capital Controls, Liberalizations, and Foreign Direct Investment, Review of Financial Studies 19, 1433-1464.

Di Giovanni, J. (2005), What Drives Capital Flows? The Case of Cross-Border M\&A Activity and Financial Deepening, Journal of International Economics 65, 127-149.

Djankov, S., McLiesh, C., and Shleifer, A. (2007), Private Credit in 129 Countries, Journal of Financial Economics 84, 299-329.

Hackethal, A. and Schmidt-Reinhard, H. (2004), Financing patterns: Measurement, concepts and empirical results.

Hausman, J., Hall, B. H., and Griliches, Z. (1984), Econometric Models for Count Data with an Application to the Patents-R\&D Relationship, Econometrica 52, 909-38.

Hawkins, R. G. and Macaluso, D. (1977), The Avoidance of Restrictive Monetary Policies in Host Countries by Multinational Firms, Journal of Money, Credit and Banking 9, 562-71. 
Head, K. and Mayer, T. (2013), Gravity Equations: Workhorse, Toolkit, and Cookbook, CEPR Discussion Paper, No. 9322.

Heston, A., Summers, R., and Aten, B. (2011) Penn World Table Version 7.0: Center for International Comparisons of Production, Income and Prices at the University of Pennsylvania.

Klein, M. W., Peek, J., and Rosengren, E. S. (2002), Troubled Banks, Impaired Foreign Direct Investment: the Role of Relative Access to Credit, American Economic Review 92, 664-682.

Kroszner, R. S., Laeven, L., and Klingebiel, D. (2007) , Banking Crises, Financial Dependence, and Growth, Journal of Financial Economics 84, 187-228.

Krugman, P. (2000), Fire-Sale FDI, in S. Edwards ed. Capital Flows and the Emerging Economies: Theory, Evidence, and Controversies: University of Chicago Press, Chap. 2, 43-60.

Laeven, L. and Valencia, F. (2013), Systemic Banking Crises Database, IMF Economic Review 61, $225-270$.

Levine, R. (2005), Finance and Growth: Theory and Evidence, in P. Aghion and S. Durlauf eds. Handbook of Economic Growth: Elsevier, Chap. 12, 865-934.

Manova, K. (2013) , Credit Constraints, Heterogeneous Firms, and International Trade, Review of Economic Studies 80, 711-744.

Manova, K., Wei, S.-J., and Zhang, Z. (2011), Firm Exports and Multinational Activity Under Credit Constraints, NBER Working Paper, No. 1905.

Rajan, R. G. and Zingales, L. (1998), Financial Dependence and Growth, American Economic Review $88,559-86$.

Reinhart, C. M. and Rogoff, K. S. (2010), From Financial Crash to Debt Crisis, NBER Working Paper, No. 15795. 
Santos Silva, J. M. C. and Tenreyro, S. (2006), The Log of Gravity, Review of Economics and Statistics $88,641-658$.

(2011) , Further Simulation Evidence on the Performance of the Poisson Pseudo-Maximum Likelihood Estimator, Economics Letters 112, 220-222.

Sauvant, K. P. (2009), Is the United States Ready for FDI from China? Overview, in K. P. Sauvant ed. Investing in the United States.

UNCTAD (2010) World Investment Report 2010: Investing in a Low-Carbon Economy: New York and Geneva: United Nations.

Westerlund, J. and Wilhelmsson, F. (2011), Estimating the Gravity Model Without Gravity Using Panel Data, Applied Economics 43, 641-649.

Winkelmann, R. (2008) Econometric Analysis of Count Data: Berlin: Springer-Verlag Berlin Heidelberg.

Wooldridge, J. M. (2010) Econometric Analysis of Cross Section and Panel Data: Cambridge, MA: The MIT Press, second edition. 


\section{Appendices}

\section{A Electronic sources of data}

- FDI data: FDI Intelligence, a division of the Financial Times. http://www. FDImarkets. $\mathrm{com} /$

- Quantitative measures of financial development: Financial Development and Structure Dataset. http: //go.worldbank .org/X23UD 9QUX0

- Institution-based measure of financial development: Doing Business database. http://www . doingbusiness.org/data/exploretopics/getting-credit

- Sector-specific value added: UNIDO Industrial Statistics Database (INDSTAT4), http : / / www . unido.org/en/resources/statistics/statistical-databases.html

- Income: Penn World Tables 7.0. http://www.rug.nl/research/ggdc/data/pwt/ ? lang=en

- Human capital: Barro-Lee database. http://www.barrolee.com/

- Institutional quality: Heritage Foundation. http: / /www . heritage.org/index/

\section{B Comparison of fDi Markets FDI flows with UNCTAD-BOP FDI}

\section{flows}

Figure A1 plots the cumulated values of outward and inward manufacturing greenfield FDI over the period 2003-2010 against economy-wide FDI flows compiled by UNCTAD on the basis of BOP statistics. 
Figure A1: fDi Markets FDI flows vs.UNCTAD-BOP FDI flows
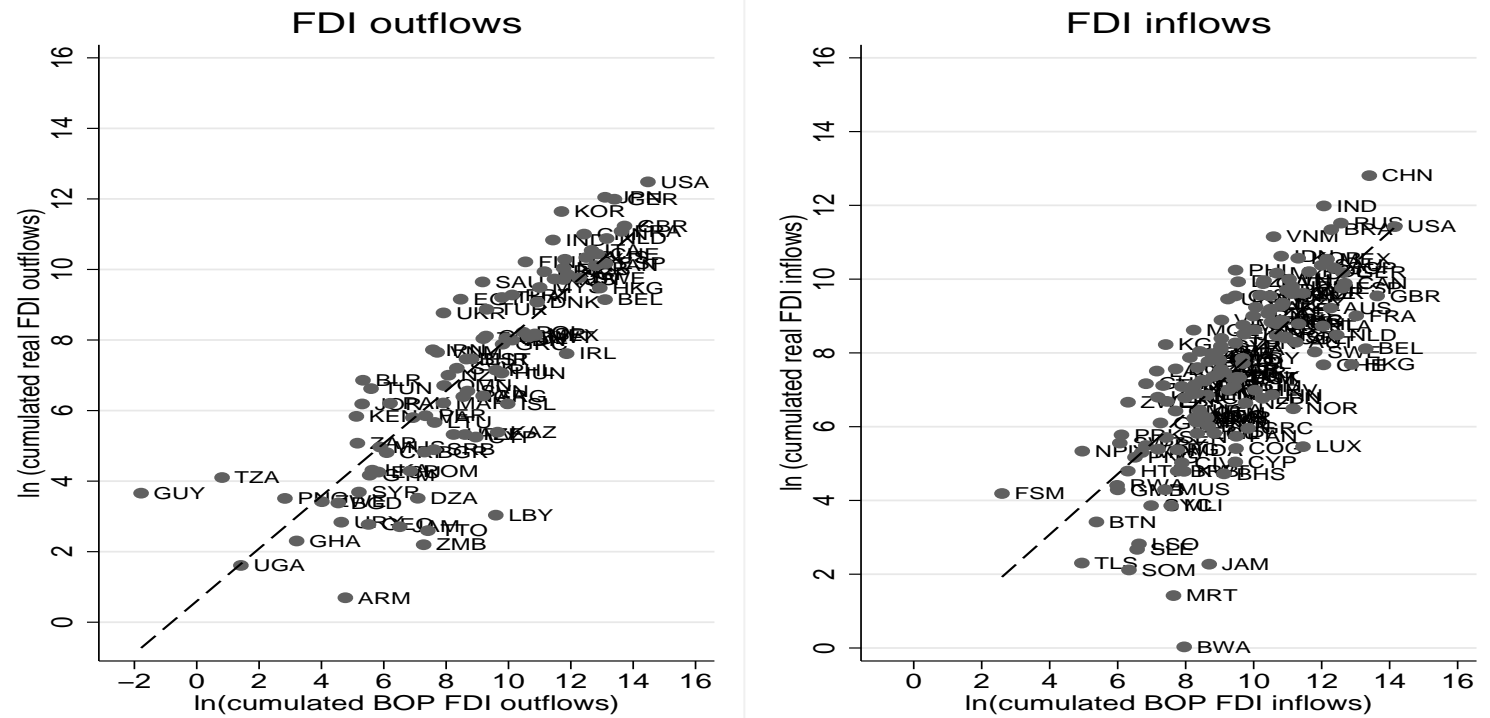

Note: Cumulated values over the period 2003-2010. fDi Markets FDI flows: manufacturing sectors only; UNCTAD-BOP FDI flows: all sectors.

\section{Measures of financial vulnerability and matching with FDI data}

The fDi Markets database classifies the FDI projects into very broad recipient sectors, which are loosely aligned with 1987 U.S. SIC codes. We match the manufacturing broad sectors to the corresponding three-digit ISIC codes (rev.2) reported in Rajan and Zingales (1998) and Kroszner et al. (2007); when the fDi Markets categories covered several sectors, we used the median value of the financial vulnerability measure for these sectors. ${ }^{31}$ Table A1 indicates how the matching was done.

\footnotetext{
${ }^{31}$ We always use the ED value for the three-digit broad ISIC sectors. In some cases, these broad sectors may not include data on subsectors, for which Rajan and Zingales (1998) and Kroszner et al. (2007) provide four-digit level specific ED values.
} 
Table A1: Measures of sectors' financial vulnerability

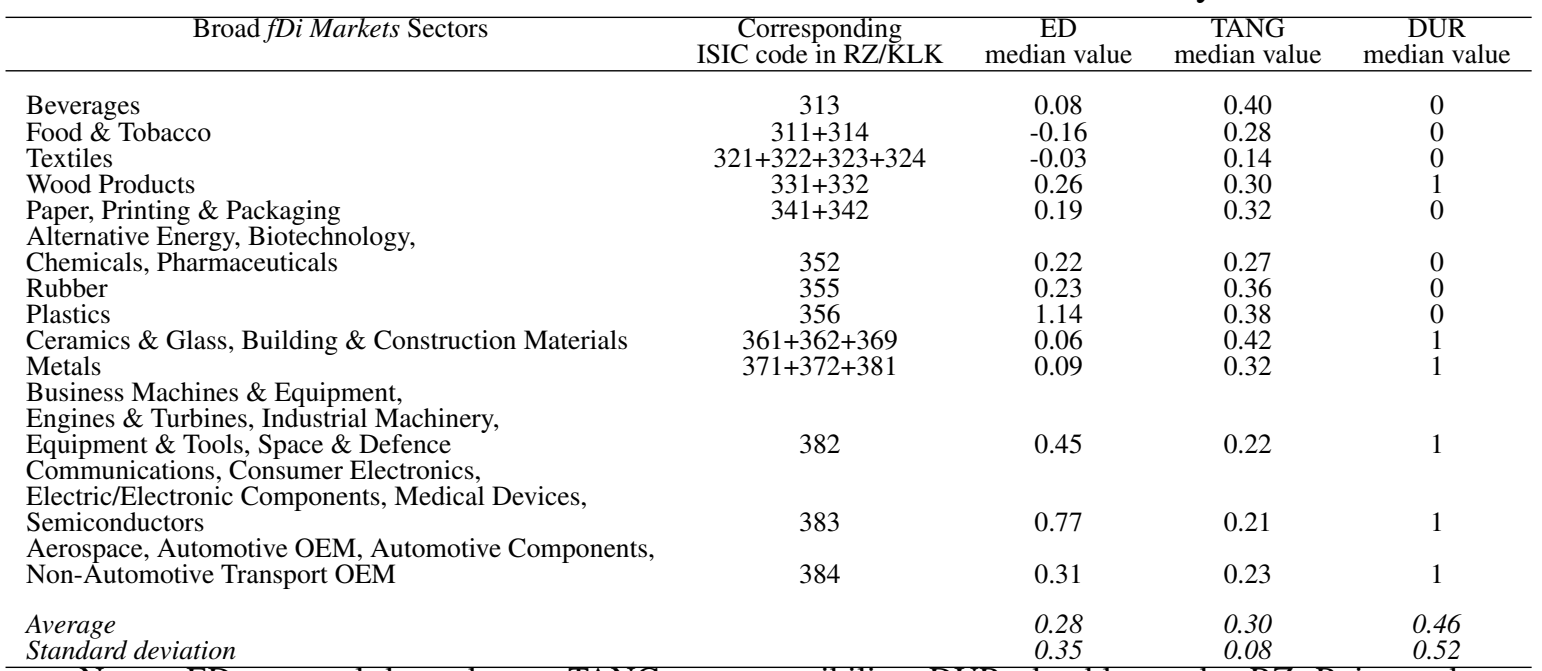
Notes: ED: external dependence. TANG: asset tangibility. DUR: durable goods. RZ: Rajan and Zingales (1998), KLK: Kroszner et al. (2007).

\section{Summary statistics}

Table A2: Summary statistics

\begin{tabular}{lrrrr}
\hline \multicolumn{1}{c}{ Variable } & Mean & Std. Dev. & Min. & Max. \\
\hline Bilateral FDI flows (US\$ millions) & 22.348 & 183.364 & 0 & 10031.4 \\
Bilateral number of FDI projects & 0.218 & 0.859 & 0 & 41 \\
Average bilateral value of FDI projects & 102.762 & 302.762 & 0.03 & 8940 \\
S. private credit to GDP ratio & 1.015 & 0.493 & 0.008 & 2.046 \\
D. private credit to GDP ratio & 0.58 & 0.484 & 0.008 & 2.046 \\
S. financial institutions & 11.281 & 3.187 & 1 & 16 \\
D. financial institutions & 9.351 & 3.642 & 0 & 16 \\
S. banking crisis & 0.5 & 0.5 & 0 & 1 \\
D. banking crisis & 0.258 & 0.438 & 0 & 1 \\
S. systemic banking crisis & 0.355 & 0.478 & 0 & 1 \\
D. systemic banking crisis & 0.163 & 0.369 & 0 & 1 \\
S. alternative banking crisis & 0.758 & 0.428 & 0 & 1 \\
D. alternative banking crisis & 0.542 & 0.498 & 0 & 1 \\
S. GCR change in credit conditions (\%) & -17.441 & 14.162 & -52.328 & 43.714 \\
D. GCR change in credit conditions (\%) & -8.929 & 15.272 & -52.328 & 43.714 \\
\hline
\end{tabular}

Table A3: Correlation coefficients of crisis indicators (destination countries)

\begin{tabular}{lccccc}
\hline \multicolumn{1}{c}{ Variables } & CREDIT/GDP & BCRIS & SYS_BCRIS & ALT_BCRIS & CH_CRED \\
\hline CREDIT/GDP & 1.000 & & & & \\
BCRIS & 0.350 & 1.000 & & & \\
SYS_BCRIS & 0.450 & 0.748 & 1.000 & & \\
ALT_BCRIS & 0.326 & 0.472 & 0.334 & 1.000 & \\
CH_CRED & -0.300 & -0.618 & -0.618 & -0.482 & 1.000 \\
\hline
\end{tabular}

